\title{
The variation of the subjunctive II in Austria
}

\section{Evidence from urban and rural analyses}

\author{
Ludwig Maximilian Breuer and Anja Wittibschlager \\ Austrian Academy of Sciences University of Vienna
}

The primary goal of this paper is to investigate areal-horizontal as well as the social-vertical (morpho-)syntactic variation of subjunctive II in urban and rural areas in Austria. The data come from two different corpora that consist of spoken data gathered in two different projects on German in Austria, collected using the method of Language Production Experiments. The high degree of comparability of our data between the two studies highlights the success and reliability of this elicitation method. Beyond this methodological insight, the study has found a global tendency towards a decline of synthetic subjunctive II constructions, whereas periphrastic constructions show an increase, both in more dialect and more standard oriented registers. Our findings further suggest that the city of Vienna exerts a minor influence on neighboring locations regarding the use of subjunctive II forms. At the same time, our data provide evidence for a more decisive influence of the dialect region.

Keywords: sociolinguistics, dialectology, subjunctive II, morphosyntactic variation, urban language, German in Austria, Language Production Experiments

\section{Introduction}

This contribution discusses variation in German in Austria by using a morphosyntactic variable. More specifically, this article investigates the variation of subjunctive II constructions like 'Ich ginge in die Schule.' 'Ich würde in die Schule gehen.,' 'I dad/darad ind Schui geh.' or 'I gangad ind Schui.' ('I would go to school.') 
in Austria (see Section 3 and Table 3). ${ }^{1}$ Thus, a morphosyntactic 'variable' with a high number of different variants that are determined by morphological as well as syntactic aspects. ${ }^{2}$ The subjunctive II is prevalent in the German speaking areas, regardless of variety, genre and speaker (Zifonun et al. 1997:1785) and provides a great richness of variants, especially considering the entire vertical dialect-standard axis. Despite its morphosyntactic complexity and its high affinity towards socio-situational as well as areal variation, the subjunctive II in Austria has been largely neglected in previous research. There are only very few studies that investigate the subjunctive II in German in Austria (e.g. Glauninger 2008; Bercko 2018; Stöckle submitted). Our paper aims to close this research gap through analyses focusing on both urban and rural areas. Thereby we combine dialectological research paradigms with those of urban language research and bring together at least two approaches: traditional dialectology or areally (horizontal) oriented variationist linguistics on the one hand, and sociolinguistics with a focus on the vertical variation along the dialect-standard axis on the other hand. ${ }^{3}$ This will be discussed in more detail in Section 2. Moreover, while the focus on syntactic variation in the German language area (and other European contexts) - at least in terms of areal-horizontal variation within dialects - has received increased attention in the last 10 to 20 years (see e.g. Lenz 2016; Lenz et al. 2019), studies on the 'vertical' grammatical variation on the dialect-standard axis are still rare (see e.g. Kallenborn 2016; Breuer i. prep.). This lack of research especially holds for urban communities.

The article analyzes parts of two distinct oral corpora to carry out a language variation study: a corpus of urban data and a corpus of rural data. Whereas empirical research on syntactic variation traditionally uses (written) questionnaires and

1. We prefer the term subjunctive II (similar to German Konjunktiv II) over the term past subjunctive (German Konjunktiv Präteritum), which we consider misleading. Despite the use of the preterit stem in forming the subjunctive II, we assume that subjunctive mood is essentially atemporal in its function (see e.g. Glauninger 2011) Despite the atemporality, it is possible to refer to past/future actions in the subjunctive II paradigm by using the auxiliary verbs haben 'have' or sein 'be' + past participle. As such forms play a minor role in our corpus (in terms of frequency), we do not go into detail and did not analyze these forms in Section 6.

2. The terms 'variables' and 'variants' - even if commonly used in variationist linguistic studies - are controversially discussed, especially for syntactic purposes (e.g. see Labov 1978; Lavandera 1978; Cheshire 2005; Auer/Voeste 2012; Kallenborn 2016). We understand a 'variable' as an abstract (functional) category, which can be expressed by concrete 'variants' (see Lüdeling 2017:129-130). For empirical purposes, a variable can be defined as abstract as needed, depending on the (inter- and extra-linguistic) influence factors analyzed (see Breuer i. prep.).

3. See Chambers/Trudgill 1998; Auer 2005; Lenz 2010 for a cone model combining the arealhorizontal and the vertical-social dimension of variation. 
(oral) interviews, our data derive from the innovative elicitation method of 'language production experiments' ('LPEs' in the following, see Lenz et al. 2019). LPEs are controlled and standardized settings, which makes them an adequate source for comprehensive (morpho-)syntactic analyses (see Breuer/Bülow 2019).

Besides proving the adequacy of the method and the comparison of two different data sets, the empirical findings will address particularly the following research questions:

1. In terms of a methodological result: Do the methods allow for the elicitation of variation on the horizontal as well as vertical axis? How suitable is the data for making comparisons between the two studies (with different survey setups and goals)? Are the methods successful in eliciting (relevant) subjunctive II variants?

2. How are different variants of subjunctive II areal-horizontally distributed in Austria? From a synchronic perspective, can we observe an influence of the urban area Vienna on the choice or frequency of specific variants used in rural areas? Or is the belonging to a dialect region a more decisive factor for rural locations than the proximity to Vienna?

3. How are different variants of subjunctive II interindividually distributed in the different speaker groups? Can we observe preferred variants depending on age or urbanity? Can we observe dynamical variation in terms of the apparent-time-hypothesis?

4. How are different variants of subjunctive II intersituationally distributed in the different survey settings? Can we identify variants, which are associated with more informal or more formal settings and therefore recognizable as more dialect near or more standard near? Can we discover (morpho-)syntactic variation on the dialect-standard-axis?

The paper is structured as follows: We start by providing a short overview of the current state of research regarding areal and vertical distribution of the various subjunctive II variants in German in Section 2. In Section 3, we present the different morphological and syntactic constructions, which German and its 'Bavarian' language area provide, as well as the functions of the subjunctive II. The following Section 4 presents the informants and research locations of the studies. We then focus on the methodological approaches that are the basis for the two corpora involved in Section 5. Section 6 then provides the empirical findings of the different dimensions of variation found in the corpora. The article closes by answering the previously formulated research questions. 


\section{State of research}

Before addressing the subjunctive II in German varieties (in Austria), we consider the wider research context and offer a short outline of the current state of research on horizontal and vertical variation in grammar with a focus on urban language research.

Whereas the focus of traditional dialectology of German was almost exclusively on phonetics/phonology, the field of grammar has attracted more attention lately. This growing interest is reflected, among other things, in syntax oriented atlases and publications (see e.g. Bucheli/Glaser 2002; Barbiers et al. 2005; Fleischer et al. 2017). ${ }^{4}$

Beyond dialects, modern variationist linguistics not only focuses the horizontal dimension, but also integrates vertical and thereby sociolinguistic approaches. There is an increasing theoretical, as well as empirical, interest in the vertical dialect-standard-axis (see e.g. Lenz 2003, 2010; Schmidt/Herrgen 2011). Again, most studies of the vertical dimension of variation focus on phonological aspects (see e.g. Fanta-Jende i.p.) rather than on morphology or syntax. Besides the pioneering work of Kallenborn (2016) on (morpho-)syntactic variation in Moselle Franconian in West Central German, a number of recent studies contribute to reducing this gap in the research for rural areas in Austria by investigating different phenomena. Korecky-Kröll (accepted) analyzes adjective gradation, Fingerhuth/Lenz (i.p.) investigate variation and change of Complementizer Agreement and Lenz et al. 2019 deal with the phenomenon GET-passive.

While urban areas have always been a focus in sociolinguistics, in the German speaking areas more dialect and areal variation centered research has rarely been done on cities (Dingeldein 2002: 22-31). For a linguistic approach that combines the horizontal and vertical approaches, urban areas are particularly interesting due to their high potential for variation (Lenz 2003:45-46). Throughout Europe urban language research has advanced to a field of high topicality in the last years (see e.g. Cheshire et al. 2011; Wiese i.p.; Ziegler et al. accepted).

Regarding urban areas in Austria, a considerable number of studies explore different aspects of the German varieties in Vienna - the capital of Austria. ${ }^{5}$ While there is a lack of comprehensive studies on the whole complex of varieties

4. For a more comprehensive list, see the homepage of EdiSyn (http://www.dialectsyntax.org /wiki/About_Edisyn), a platform aiming to connect the diverse projects on dialect syntax in Europe.

5. While we focus on Vienna, other urban areas in Austria are considered in different publications, mainly focusing language attitudes (Moosmüller 1991; Steinegger 1998) or particular phenomena or aspects of variation (e.g. youth language see e.g. Lenzhofer 2017). 
in different registers and in relation to contact phenomena to other languages (Tatzreiter 2002: 128), many studies focus on single phenomena, especially on the level of phonetics/phonology (see e.g. Moosmüller 1987; Wiesinger 1995) or lexis (see e.g. Wehle 1980; Hornung/Grüner 2002; Glauninger 2010). There are a few studies on morphological or syntactic phenomena (e.g. Patocka 1997; Glauninger 2008, 2011). Studies concerning vertical variation of grammatical variables in Vienna can be found in Breuer (2016, 2017a and 2017b).

Concerning the variation of subjunctive II in German varieties, the (empirically founded) knowledge about the horizontal and especially the vertical variation is limited. Even though the form, and the global scope of application of the subjunctive mood, is discussed in most grammars (see e.g. Merkle 1975; Zehetner 1985; Zifonun et al. 1997; Eisenberg 2013; Duden 2016), there are only a few studies on the subjunctive II in the Bavarian-Austrian language space. Among those are Glauninger (2008, 2011), working on the Viennese subjunctive II, Lenzhofer (2017) investigating youth language in East Tyrol, Lenz (2017) analyzing Wenker Questionnaires in the entire German speaking area and Stöckle (submitted) dealing with data collected in the first half of the 2oth century in the context of the 'Wörterbuch der bairischen Mundarten in Österreich' (WBÖ) ('dictionary of Bavarian dialects in Austria'). The 'Atlas der deutschen Alltagssprache' (AdA) ('Atlas of colloquial German') maps subjunctive II constructions in colloquial German focusing on 'intermediate' varieties, which are also the focus of Bercko's (2018) pilot study on urban and rural areas in South/Central Bavarian.

Among the periphrastic subjunctive II forms (with würde or tun) (see Section 3), it is the würde-construction that has received more attention in literature on German (see e.g. Fabricius-Hansen 2000, Smirnova 2006, Auer 2007; Brooks 2015). The tun-subjunctive is rather dealt with peripherally in articles on the tun-periphrasis (see e.g. Wiesinger 1989; Schwarz 2009).

In the following Section 3, we provide a short overview of the state of research on the German subjunctive II. This will underline why our focus closes a research gap by combining not only the horizontal and vertical approach to variation but also the comparison between rural and urban areas with a focus on syntactic variation. The subjunctive II, with its high number of variants, promises a particularly high variation potential to illustrate our methodical and theoretical approach to the research questions listed in Section 1. The coexistence of various varieties and its place within German as a pluricentric language renders Austria an "ideal sociolinguistic research laboratory" (Lenz 2018:269) to pursue these questions. 


\section{Constructional and functional aspects of the German subjunctive II}

We will now provide an overview of the subjunctive II in Standard German as well as the Bavarian dialects and therefore the considered variants of the analyzed variable. To illustrate the broad spectrum of variants, we will provide some selected examples from the urban and the rural corpus. As described in Section 4, while the rural corpus comprises the entire Austrian language area, our article focuses on spoken data of Austrian Bavarian varieties from 'autochthonous' speakers, which are surveyed in different areas all over Austria (see Figure 1). As the surveys were conducted in two different experimental settings, the examples show data from the dialect oriented experiment run (LPE-d) and the standard oriented experiment run (LPE-s) (see Section 5 for further detail).

In Standard German, there are two competing strategies for building the subjunctive II: synthetic morphological and analytic syntactical constructions. Regarding Standard German, as described in normative grammars, the subjunctive II is formed by adding the subjunctive II endings (see Table 1) to the preterit stem of the verb. In case of irregular verbs they receive an umlaut if the stem vocal is $a, o$ or $u$.

Table 1. Subjunctive II endings of irregular and regular verbs

\begin{tabular}{|c|c|c|}
\hline & \multicolumn{2}{|c|}{ Subjunctive II } \\
\hline & Irregular verbs & Regular verbs \\
\hline $1 \mathrm{SG}$ & $-e$ & -(e)te \\
\hline $2 S G$ & -est & -(e)test \\
\hline $3 \mathrm{SG}$ & $-e$ & -(e)te \\
\hline $1 \mathrm{PL}$ & -en & -(e)ten \\
\hline $2 \mathrm{PL}$ & -et & -(e)tet \\
\hline $3 \mathrm{PL}$ & -en & -(e)ten \\
\hline
\end{tabular}

The subjunctive II form of regular verbs coincides with the preterit indicative (see (1)). Subjunctive II and indicative forms can only be distinguished for some inflectional forms of irregular verbs (see (2), see Duden 2016).

(1) Synthetic subjunctive II with regular verbs (identical to preterit) Ich wohnte am Mond. ${ }^{6}$

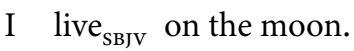

'I would live on the moon.'

6. Since we could not find a single example of a synthetic subjunctive II conforming to the standard norm with regular verbs in the provided data on Standard Language (see Section 5), this example is constructed. 


\section{(2) Synthetic subjunctive II with irregular verbs}

Es gäbe bestimmt viele interessante Aufgaben zu meischtern.

It give ${ }_{\mathrm{SBJV}}$ definitely many interesting challenges to master $_{\mathrm{INF}}$.

'There were definitely many interesting challenges to master.'

(rural, LPE-s, TKo228_YM_H) ${ }^{7}$

To avoid syncretic forms, the norm for Standard German allows the periphrastic construction with the finite auxiliary verb würde and the infinitive of the main verb ((see (3), see e.g. Glinz 1994:132, Duden 2016:165). Described as a disambiguating construction, the würde-periphrasis is generally accepted and frequently used in spoken Standard German (see e.g. Glinz 1994:132, Duden 2016:167). This replacement of synthetic forms also applies for unambiguous irregular verbs, apart from a number of highly frequent irregular verbs (e.g. haben 'have', sein 'be', kommen 'come', geben 'give' (Zifonun et al. 1997:1784)) and modal verbs (Duden 2016). Apart from these frequent forms, the synthetic subjunctive II constructions are largely restricted to written language, but tend to be replaced by the würde-periphrasis even in formal written contexts (Duden 2016).

(3) Periphrastic subjunctive II with auxiliary würde

Ich würde einen Planeten besuchen, [...].

I would $_{\mathrm{SBJV}}$ a planet visit $_{\mathrm{INF}}, \quad[\ldots]$.

'I would visit a planet, [...]'

(urban, LPE-s, VIEo5_YM_H)

Non-standard varieties show a number of further variants. In Austrian Bavarian non-standard varieties there is, particularly for irregular verbs, the option to form a subjunctive II by undergoing ablaut (see (4); see Zehetner 1977: 117, Wiesinger 1989:56). The subjunctive II repertoire of Austrian Bavarian non-standard varieties furthermore contains the ad-marker. Added to the verb stem, this $a d$-morpheme creates unambiguous subjunctive II forms. While the $a d$-subjunctive originally existed solely in combination with regular verbs, it has nowadays exceeded its scope to irregular verbs that can also be suffigated with -ad to mark subjunctive II (see Salveit 2008: 1224). The ad-suffix can either be attached to the present (see (5)) or to the preterit stem (see (6)). Additionally, the $a d$-suffix can be combined with the subjunctive II built by undergoing ablaut (e.g. gangad, 'would go') (see Zehetner 1985). In Bavarian, all these three forms can possibly coexist for a single verb (e.g. gehad, gingad, gangad, 'would go').

7. Apart from the copora (urban, rural) and the run of the LPE (LPE-s and LPE-d) from which the examples derive, abbreviations are used to provide additional information on the speakers. In the first place is the ID of the research location (see also Table 2) followed by the identification number of the speakers used within the studies. The next information refers to age ( $\mathrm{Y}=$ young, $\mathrm{O}=$ old $)$ and gender as well as the formal education $(\mathrm{L}=$ low, $\mathrm{H}=$ high). 
(4) Synthetic subjunctive II with ablaut

Do gang $i$ in a Reisebüro.

Then go $_{\text {sBJv }} I$ in a travel agency.

'Then I would go into a travel agency'

(rural, LPE-d, TAo243_YM_L)

(5) Synthetic subjunctive II with - ad attached to the present stem

I regad mi sicherned auf.

I complain-ad ${ }_{\mathrm{SBJV}}$ myself sure not.

'I would definitely not complain.'

(rural, LPE-d, STo614_OM_L)

(6) Synthetic subjunctive II with -ad attached to the past stem

Da kamad I mit olle meine Schuifreind zam.

Then come-ad ${ }_{\mathrm{SBJv}}$ I with all my school friends together.

'Then I would meet up with all of my school friends.'

(rural, LPE-d, NMo209_OF_L)

Although hardly any preterital forms are used in Austrian Bavarian varieties and the need for disambiguation is therefore not given, periphrastic forms as the ones mentioned above (see (3)) for Standard German are also possible in non-standard varieties. As Example (7) shows, in addition to the synthetic forms, the Bavarian subjunctive II can be represented periphrastically with the auxiliary würde, which is common in Standard German. Lexically there is another option as auxiliary verb in Bavarian (as in many other German) non-standard varieties (see e.g. Lenz 2017, AdA) and the periphrastic subjunctive II can also be built with tun (see (8), see e.g. Wiesinger 1989:56, Eroms 1998).

(7) Periphrastic subjunctive II with auxiliary würde

[...] ich würde alles alleine machen.

[...] I would $_{\mathrm{SBJV}}$ everything alone do/make $\mathrm{INF}$.

'[...] I would do everything by myself'. (urban, LPE-d, VIEo3_OF_L)

(8) Periphrastic subjunctive II with auxiliary tun

[...] und dann dat $i$ den ganzen Tog spielen.

$[\ldots]$ and then $\mathrm{do}_{\mathrm{SBJV}} \mathrm{I}$ the whole day play ${ }_{\mathrm{INF}}$.

'[...] and then I would play the whole day long.' (rural, LPE-d, WBoo52_YF_L)

Abraham and Fischer (1998) state that würde is not common in Alemannic and Bavarian dialects in Austria and is avoided as Standard German identifier. The South Bavarian data from Lenzhofer's (2017) study support this hypothesis partially. The würde-subjunctive is documented among South Tyrolian teenagers, though very rarely (see Lenzhofer 2017: 295f.) In contrast, there is empirical evidence for the expansion of the würde-periphrasis, for example by Glauninger (2008), which is also observed in other regions of the German speaking area (see 
Kallenborn 2016 for Moselle Franconian). As würde is spreading to such a wide extent, Glauninger assumes a gradual establishment of a universal subjunctive form in spoken as well as written contexts (see Glauninger 2008:242). An aspect, which all these studies share, is that they all register an expansion of periphrastic forms (with either würde or tun) at the costs of synthetic ones. ${ }^{8}$

The subjunctive II with the auxiliary täte (= subjunctive of tun 'do'), more precisely the tun-periphrasis in general, is stigmatized and considered as nonstandard (see e.g. Langer 2001). However, authors agree that the tun-subjunctive II is widely spread in non-standard varieties of Bavarian dialects in Austria (see Abraham/Fischer 1998; Brinckmann/Bubenhofer 2012; Bercko 2018). The AdA, relying on data on the 'mittleren Bereich' ('middle zone', Bellmann 1983) collected in written online questionnaires, concerns the phenomenon subjunctive II in three different maps. All three maps with data from different rounds of surveys (täte probieren (Frage 18c); tun-II (Frage 8c); brauchen (Konj.II) (Frage 4m)) support the thesis of Abraham and Fischer (1998) and show, as opposed to the remaining German speaking areas, that tun is the preferred auxiliary in subjunctive II-periphrasis in Austria (as well as South Tyrol and South Germany). Nevertheless, Glauninger (2008) comes to different results based on a corpus of spoken non-standard Viennese, in which the tun-subjunctive II plays a minor role.

There is some disagreement regarding the equivalence of the tun- and würde-periphrasis. The tun-subjunctive is often described as a non-standard counterpart of the würde-construction (see e.g. Merkle 1975:69). Abraham and Fischer (1998) disagree and claim that they have different functions. Würde + infinitive substitutes old, ambiguous subjunctive II forms. In contrast, in Bavarian dialects, in which the synthetic subjunctive II is distinctively marked, there is no need to paraphrase them. According to Eroms (1998:156), the tun-subjunctive is rather used for some other reason, for example to mark a lower register.

Regarding the lack of disambiguating properties, the periphrastic forms can be interpreted as a need for analytic constructions, especially considering the following further variant. Both strategies, the analytic periphrastic as well as the synthetic morphological, can be combined in Bavarian non-standard varieties by appending the $a d$-suffix to the corresponding auxiliary verb (mainly tun (see (9) but occasionally also würde (see (10)) (see Glauninger 2008). Thereby this 'hybrid form' doubly marks the subjunctive II function and shows the localization of the presented phenomenon in the interface between morphology and syntax.

8. The only evidence that points in the opposite direction known to us comes from Bittner/ Köpcke (2010) who find a tendency towards strong synthetic subjunctive II forms in their study with artificial verbs. 
(9) Periphrastic subjunctive II with auxiliary tun combined with -ad I darad de gesomte Bürokratie ooschoffen.

I do- $\operatorname{ad}_{\mathrm{SBJV}}$ the whole bureaucracy abolish ${ }_{\mathrm{INF}}$.

'I would abolish the whole bureaucracy'? (rural, LPE-d, STo622_YF_L)

(10) Periphrastic subjunctive II with auxiliary würde combined with -ad

$J a$, da wuatad ischo d_Lehreringaweng segieren.

Yes, then would-ad ${ }_{\mathrm{SBJV}}$ I certainly the teacher a little bit pester ${ }_{\mathrm{INF}}$ *

'Yes, I would certainly pester the teacher a little bit.'

(rural, LPE-d, TK_0443_OF_L)

These 'hybrid forms', with a suffixed auxiliary, are, according to the 'dictionary of Bavarian dialects in Austria' (WBÖ), documented in Vienna and surrounding areas (see Glauninger 2008). Yet Glauninger (2008) did not find examples for those subjunctive II forms among the younger generation.

We now end the discussion of the forms the subjunctive II can take and briefly discuss two of its functions central to the empirical findings in Section 6: the function as irrealis (see (11)) or potentialis (see (12)), which are the two core functions of the subjunctive II. (for discussion of further functions, see e.g. Donhauser 1992; Glinz 1994; Glauninger 2011; Duden 2016).

Constructed examples

(11) Irrealis

An deiner Stelle käme ich nicht.

At your place come ${ }_{\text {sвJv }} \mathrm{I}$ not.

'If I was in your place, I would not come.'

\section{(12) Potentialis}

Würde am Nachmittag die Sonne scheinen, ginge ich in den Park. Will $_{\mathrm{SBJV}}$ at the afternoon the sun shine ${ }_{\mathrm{INF}}, \mathrm{go}_{\mathrm{SBJV}} \mathrm{I}$ in the park. 'If the sun would shine in the afternoon, I would go to the park.'

The German subjunctive II occurs mainly in statements with restricted validity and often appears in wishes, demands and expectations (see Merkle 1975; Duden 2016:159ff.). The subjunctive II in its function as irrealis (see (11)) is used to express situations contrary to fact, whereas the potentialis signals that the situation does not correspond to the reality but can possibly come true (see (12)). 


\section{Study frameworks, informants' sample and research locations}

As stated above, to address our research questions, two studies on language variation in German in Austria were conducted. The urban study focusses the capital Vienna, the rural study investigates rural areas in Austria and have different overall setups. While the urban data is collected in a set-up focusing on (morpho-)syntactic variables and socio-communicative factors influencing the use of specific variants, the rural data is part of a set-up, which aims to survey, document and analyze speech repertoires and varietal spectra in rural regions in Austria. The main innovative aspect thereby is that it analyzes horizontal and vertical variation throughout Austria and focuses on different linguistic levels - a research desideratum, as implied in Section 2 (see also Koppensteiner/Lenz 2017; Lenz 2018; Budin et al. 2019). These different overall goals lead to slightly different survey settings for and differences in the specific tasks in the studies.

Both studies use a wide range of methods to survey the entire varietal spectrum of individuals: Conversational spoken data (guided interviews, conversations among friends) and standardized spoken data in controlled settings are collected. The controlled settings include, inter alia, language production experiments (LPEs) that are especially designed to elicit (morpho-)syntactic phenomena (see Section 5; for further tasks in the rural study see e.g. Lenz 2018). The experimental data were collected in two different runs (and in the urban study even in different sessions) with a different situational setup: a formal situation aiming at more standard-conform varieties and an informal situation for more non-standard/dialectal varieties (see Section 5).

As well as considering variation, the methods must also take note of the design of the informants' sample. Regarding the horizontal dimension, in the rural set-up we collected data in 13 rural research locations (see Figure 1), representing different dialect subareas, spread all over Austria (for further selection criteria of the locations see Koppensteiner/Lenz 2017: 58, Fingerhuth/Lenz i.p.). For our rural study presented here, we have limited the analyses to 11 locations in the Bavarian dialect area and its transition area to the Alemannic area. These are Tarrenz in the Alemannic/Bavarian transition zone, Weißbriach, Oberwölz and Tux in the South Bavarian area, Hüttschlag, Passail and Neckenmarkt in the South/ Central Bavarian transition area, Steyrling, Neumarkt/Ybbs and Gaweinstal in the East-Central Bavarian area and Taufkirchen/Pram representing West-Central Bavarian. The remaining two rural locations are excluded from the corpus here. Raggal is located in the Alemannic area of Austria, and therefore does not match our focus on Bavarian varieties of German, in Allentsteig (East-Central Bavarian) further surveys are required. 
As mentioned before, for the urban data we focus on the complex variation structure in one city: Vienna, which belongs to the East Central Bavarian dialect area. As previously mentioned (see Section 2), big cities, as Vienna, are described as influential on the surrounding areas. Vienna, as the biggest city in Austria, capital of the country, has, inter alia, therefore a high socio-economic potential and cultural prestige (see Breuer/Glauninger 2012:2), and recommends itself for comparison to rural areas in Austria.

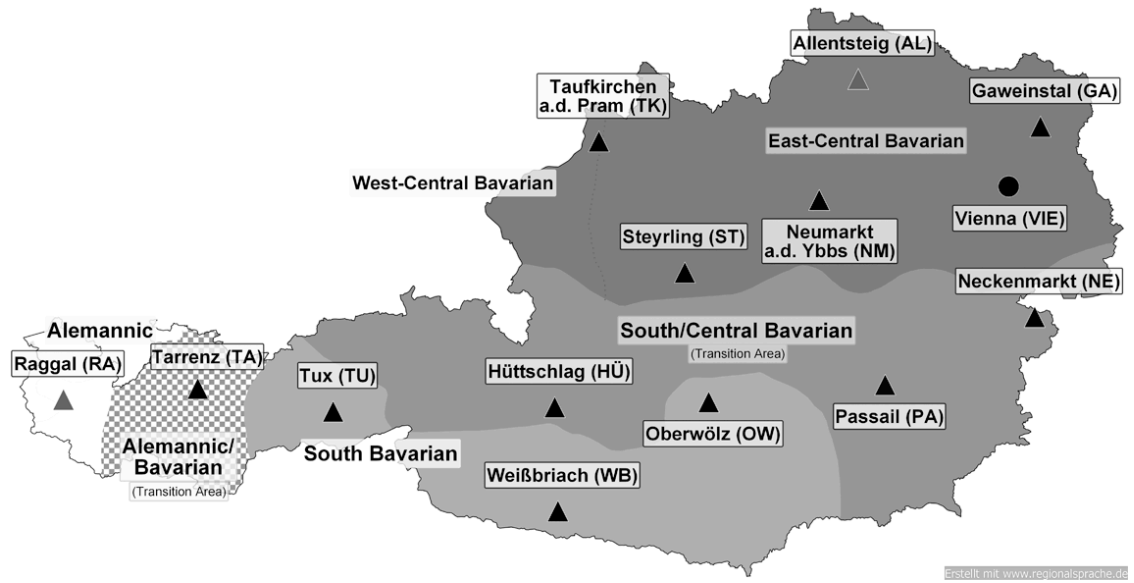

Figure 1. Urban and rural research locations (locations with black triangles are, in contrast to the grey ones, considered in the analyses in Section 6) (CC-BY-SA Melanie Seltmann 2019|regionalsprache.de)

The rural set-up aims for at least 10 informants for each location, until the analyses for the present article, a total of 138 informants from all these research locations participated. ${ }^{9}$ The survey of the urban study is conducted using 32 informants from Vienna. All informants in both studies live up to the criterion of 'autochthony', which is fulfilled by our definition if at least one of the informants' parent is native to the investigated area and if the speaker themselves have spent the majority of their lives on-site.

For the integration of both, the vertical and dynamic dimension (apparent time approach, see Weinreich/Labov/Herzog 1968:184, Chambers/Trudgill 1998: 149ff.), the selection of informants is motivated by socio-demographic parameters besides geographical affiliations. Following Lenz (2003) age, gender, regional mobility and the level of education are considered. One group of the rural infor-

9. Compilation of the rural corpus is still ongoing. Therefore, data of further informants will be added to the corpus in the future. (Date of retrieval of the data: November 2018) 
mants consists of classic NORMs and NORFs older than 60 years. The second group includes individuals aged 18-35, most of them commuters. These younger speakers are divided into two groups according to their level of formal education. We aim to have a balanced ratio between male and female informants in all groups of speakers. All urban age groups are divided according to their level of formal education, the young group includes informants aged 18-30, the older group consists of individuals older than 60 years. An additional intermediate age group (between 31 and 60 years) participated. As there is no rural comparison group to the middle-aged group, we limit ourselves to the two other groups. The previously mentioned restrictions on both places lead to the informants' sample shown in Table 2.

Table 2. Speakers per research location for the present article

\begin{tabular}{lccccc}
\hline Research location & ID & Dialect area & Young speakers & Old speakers & Total \\
\hline \multicolumn{7}{c}{ Urban corpus } \\
\hline Vienna & VIE & East-Central Bavarian & 12 & 4 & 16 \\
\hline \multicolumn{7}{c}{ Rural corpus } \\
\hline Gaweinstal & GA & East-Central Bavarian & 7 & 2 & 9 \\
Hüttschlag & HÜ & South/Central Bavarian & 9 & 2 & 11 \\
Neckenmarkt & NE & South/Central Bavarian & 7 & 5 & 12 \\
Neumarkt/Ybbs & NM & East-Central Bavarian & 8 & 3 & 11 \\
Oberwölz & OW & South Bavarian & 9 & 3 & 12 \\
Passail & PA & South/Central Bavarian & 8 & 3 & 11 \\
Steyrling & ST & East-Central Bavarian & 9 & 2 & 11 \\
Tarrenz & TA & Alemannic/Bavarian & 8 & 4 & 12 \\
Taufkirchen/Pram & TK & West-Central Bavarian & 7 & 2 & 9 \\
Tux & TU & South Bavarian & 8 & 5 & 13 \\
Weißbriach & WB & South Bavarian & 9 & 2 & 11 \\
\hline
\end{tabular}

This sample leads to the desired comparability and enables analyses on horizontal, inter-individual and intersituational variation, through the survey method we describe in the following section.

\section{Language Production Experiment for eliciting subjunctive II}

Considering the methodological base for empirical data on syntactic variation, the aforementioned lack in traditional dialectological research on syntax (see Section 2) went hand in hand with a lack of well-approved and specialized methods for these purposes. This is because mainly methods designed for phonological 
analyses (especially interview and questionnaire) were applied to survey syntax. Without going into detail (for a comprehensive discussion see Kortmann 2010; Hasty 2014; Kallenborn 2016; Breuer/Bülow 2019; Lenz et al. 2019), one of the main problems is to elicit the desired syntactic variants in a sufficient number in the inter- and extra-linguistic contexts that are to be investigated.

Confronted with the problem of relative scarcity of syntactic phenomena in corpora of spoken language, variationist research has developed different methods for the targeted elicitation of data on syntactic variants. One such method are translation tasks, which were used frequently already in early dialectology (see e.g. Rabanus 2008; Schallert 2013). Translation tasks run the risk of unduly guiding speakers' responses (Cornips/Poletto 2005:953, see however Fingerhuth/Breuer accepted for a study that calls such claims into question). Another method asks speakers for grammaticality judgements (see Cornips/Poletto 2005). While such judgement data have the advantage of providing insights into the realm of linguistic possibility, considerable disadvantages of such data concern the uncertainty about the interrelation between grammaticality judgements and language production (Labov 1975) and remains silent about speakers' preferences in language production. More recently, Language Production Experiments, using different task types, have been used as a further method for the targeted elicitation of syntactic data (see Lenz 2008, 2016; Kallenborn 2016; Fleischer et al. 2017; Breuer/Bülow 2019; Lenz et al. 2019; Fingerhuth/Breuer accepted; Breuer i.prep.)..$^{10}$ As the name suggests, the LPE is a highly standardized method, which aims at language production data, meaning mostly spoken data in controlled intra- and extra-linguistic contexts. Elicitation relies on (multimodal) stimuli (e.g. questions, completion tasks) that, for ease of implementation and documentation, are presented using computers and experiment software like Open Sesame (https://osdoc.cogsci.nl/), as is described in further detail below. There are at least three key advantages of the use of LPEs: Firstly, the LPE - at least as computer supported LPE (see Breuer/Bülow 2019) - enables a high degree of control over the procedure and simultaneously minimizes the influence of the fieldworker (see Breuer/Bülow 2019). Secondly, the LPE offers the possibility of testing different factors that could influence speakers' choice of variants (Breuer/Bülow 2019:252). Thirdly, variants can be elicited in a sufficient number. Therefore, LPEs are a valuable addition to the variationist linguistic toolkit.

10. We rate the approach as experimental (in a broader sense), in that certain factors are controlled. (see e.g. Kristiansen 2010:530, Fingerhuth/Breuer accepted) The investigated phenomenon is understood as dependent variable, the factors that may influence the occurrence / form as independent variables. As a full control over all variables is not possible, we consider, following Breuer/Bülow (2019), our experiments as quasi-experimental. For a more comprehensive debate on the term 'experiment' see Cornips/Poletto 2005; Kristiansen 2010; Fingerhuth/Breuer accepted. 
As mentioned previously, the construction of both corpora (urban and rural) relies on LPEs, which is the foundation for the following empirical findings. The concrete LPEs are very similar computer-supported LPEs that rely on the aforementioned experiment software OpenSesame. The informants interact primarily with the survey laptop, while the fieldworker is only present to start the separate tasks and for clarification if questions arise. In order to elicit the desired varieties (also see Section 4), all informants participate in two experiment-runs: one run targeting the intended standard (LPE-s) and on in the intended dialect (LPE-d). Regarding the LPE-s of the rural study, the auditory task stimuli is spoken by a trained Austrian newscaster from the Austrian Broadcasting Corporation (ORF), whereas the stimuli used in the LPE-d are location-specific and spoken by a competent local dialect speaker each. The fieldworker further instructs speakers to use their 'best Standard German' (im besten Hochdeutsch sprechen), respectively their 'individual dialect' (in ihrem eigenen Dialekt sprechen). In the urban study, the LPE-s auditory stimuli present an autochthonous professional standard speaker from Vienna, the LPE-d stimuli a further autochthonous speaker of a Viennese dialect. Here, the choice of variety was directed through different situational setups and the direction to speak as if speaking with a stranger in the LPE-s, respectively as speaking with a friend in the LPE-d.

Each LPE run consists of many different multimodal tasks aiming at evoking various (morpho-)syntactic phenomena. The LPE runs conducted in rural locations consist of 109 single tasks each (see Lenz et al. 2019), the experimental runs in Vienna of a total of 70 tasks each (see Breuer 2017a). The task sets targeting subjunctive II constructions ask participants to imagine hypothetical situations. In the urban study, they consist of two different stimuli in the LPE-s covering the topics 'owning a space shuttle and 'being able to perform magic. To avoid repetition effects, in the LPE-d in the urban study different prompts ('owing an island' and 'being able to fly') were used. In contrast, the rural study relies on four identical scenarios in LPE-s and LPE-d and uses 'lottery win', 'being chancellor', 'being a child, 'going to school' in each LPE-run. ${ }^{11}$ All stimuli used for elicitation are only auditive. Whereas the rural study orally induces a single one-sentence input (example of a full prompt: Stellen Sie sich vor, Sie gewinnen morgen zehn Millionen Euro im Lotto. 'Imagine winning ten million euros in the lottery tomorrow.), the full prompt in the urban study consists of a request to imagine the scenario and

11. Concerning the use of identical versus different scenarios, the urban and the rural study pursued different strategies. In contrast to the urban study (where the avoidance of repetition effects was striven), the rural large-scale study decided not to vary the scenarios in LPE-s and LPE-d in order to keep the variance low and to elicit similar (or even the same) verbs in both runs. 
an additional question during the elicitation process (example of a full prompt: Stellen Sie sich vor, Sie besitzen ein Raumschiff. Was tun Sie? 'Imagine owning a space shuttle. What do you do?'). As this supplementary question contains tun (not as auxiliary but main verb), participants' answers may be influenced (see Section 6.1.). The aim of all these tasks is to evoke subjunctive II constructions with a counterfactive semantics in the function of a potentialis or irrealis (see Section 3). As the subjunctive tasks are open tasks and multiple responses are permissible, the amount of answers given by the participants per task (resp. per scenario per run) varies strongly.

All rural participants' responses of both runs resulted in an average amount of 280.8 relevant answers containing a subjunctive II construction (e.g. Ich würde nicht mehr in die Schule gehen. 'I would not go to school anymore.') per task (with a minimum of 248 responses elicited in the scenario 'going to school' in the LPE-s and a maximum of 332 answers obtained in the task 'lottery win' also in the LPEs). The average amount of responses from all Viennese participants and both runs is 14.8 (with a minimum of 12 in the task 'perform magic' and a maximum of 19 relevant answers in the scenario 'island'). Responses in the indicative mood (e.g. Ich $_{\text {zaubere }}{ }_{[\mathrm{IND}]}$ ein besseres politisches System. 'I magically create a better political system.; see Section 6.1. for the percentage of indicative forms in our data) and interjections that are not related to the task in any way (e.g. Okay, mir fällt nix anderes ein. 'Okay, I cannot think of anything else.') are excluded from the analyses. The data consist of both immediate responses to the stimulus itself, as well as answers elicited by the fieldworkers through e.g. further questions (e.g. Was machen Sie, wenn Sie gewinnen? 'What will you do if you win?') contribute to the analyses. For the following empirical findings, one has to bear in mind that not only the number of answers per speaker per task but also the number of participants per location is fluctuating (as illustrated in Table 2).

\section{Empirical findings}

This section provides empirical results. The first part of the section deals with methodological aspects and aims to evaluate the applied elicitation method to analyze the morphosyntactic phenomenon subjunctive II. Therefore, we consider the variants stated in Table 3, which also give examples from the corpus (for more details see Section 3). We then examine the horizontal dimension of variation and address the dynamic and vertical dimension of variation by analyzing the interindividual use of subjunctive II forms. Lastly, we focus on the vertical dimension and observe intersituational differences. 
Table 3. Overview of the subjunctive II variants in the corpora

\begin{tabular}{|c|c|c|}
\hline Variant & Example & Translation \\
\hline Synthetic & $\begin{array}{l}\text { Wenn ich zaubern könnte, }[\ldots] \\
\text { (VIE_03_OF_L) }\end{array}$ & $\begin{array}{l}\text { If I perform } \\
\text { INF } \\
\text { ('If I could perform magic could }{ }_{\mathrm{SBJV}},[\ldots] \text { '...] }\end{array}$ \\
\hline $\begin{array}{l}\text { Synthetic } \\
+-a d\end{array}$ & Des gfreiad mi, jo. (ST_o614_OM_L) & $\begin{array}{l}\text { That please-ad }{ }_{\text {sBjv }} \text { me, yes } \\
\text { ('I would be pleased, yes.') }\end{array}$ \\
\hline $\begin{array}{l}\text { Periphrastic } \\
\text { würde }\end{array}$ & $\begin{array}{l}\text { Dann würd i ma zehn Ponys kaufen. } \\
\text { (NE_0024_YF_H) }\end{array}$ & $\begin{array}{l}\text { Then would } \\
\text { SBJV } \\
\text { buy }{ }_{\text {INF' }} \text { ' myself ten ponies } \\
\text { ('I would buy } 10 \text { ponies for myself.') }\end{array}$ \\
\hline $\begin{array}{l}\text { Periphrastic } \\
\text { würde +-ad }\end{array}$ & $\begin{array}{l}J a, \text { da wuatad } i \text { scho d_Lehrering a weng } \\
\text { segieren. (TK_0443_OF_L) }\end{array}$ & $\begin{array}{l}\text { Yes, then would-ad }{ }_{\text {SBJV }} \text { I certainly the } \text { teacher a little bit pester } \\
\text { INF' } \\
\text { ('Yes, I would certainly pester the } \\
\text { teacher a little bit.') }\end{array}$ \\
\hline $\begin{array}{l}\text { Periphrastic } \\
\text { tun }\end{array}$ & I dat viel spielen. (WB_0024_YM_L) & $\begin{array}{l}\text { I do }_{\text {SBJv }} \text { a lot play } \\
\text { ('I would play a lot.') }\end{array}$ \\
\hline $\begin{array}{l}\text { Periphrastic } \\
\text { tun +-ad }\end{array}$ & $\begin{array}{l}\text { I darad mi ois frogen trauen. } \\
\text { (ST_0632_YF_H) }\end{array}$ & $\begin{array}{l}\text { I do-ad }{ }_{\text {SBJV }} \text { myself everything ask } \\
\text { dare }_{\text {INF. }} \\
\text { ('I would dare to ask everything.') }\end{array}$ \\
\hline
\end{tabular}

\subsection{Evaluation of the experiment design}

Table 4 shows the number of responses elicited by the LPE in all research locations, divided depending on whether participants use subjunctive II or the indicative mood. In the corpus, there are 2,519 answers across both experiment runs for all tasks and all research locations combined. Among these answers, the vast majority (91.3\%) contains a subjunctive II construction, whereas only about $8.7 \%$ are in the indicative mood and as such irrelevant for the following analyses.

Table 4. Subjunctive and indicative constructions elicited by the LPE in all research locations $(n=2,519)$

\begin{tabular}{lcc}
\hline & Absolute numbers & $\%$ \\
\hline Subjunctive II & 2301 & 91.3 \\
Indicative & 218 & 8.7 \\
\hline
\end{tabular}

It's not only the high number of subjunctive II forms that are bespeaking the sufficiency of the LPEs to investigate this morphosyntactic phenomenon, but also the comparability of the elicited data, as we will show through the comparison of data from the two studies. For an evaluation of the experiment design and a verification of an interstudy comparability of the LPE data, the individual tasks used in each study (urban, rural) are compared in Figure 2 and Figure 3. As pointed out in Section 5 , the procedure as well as the tasks themselves are very similar. Figure 2 and Figure 3 illustrate the responses to the LPE-s and LPE-d and indicate major 
parallels between the single scenarios, both within the individual studies as well as across the studies.

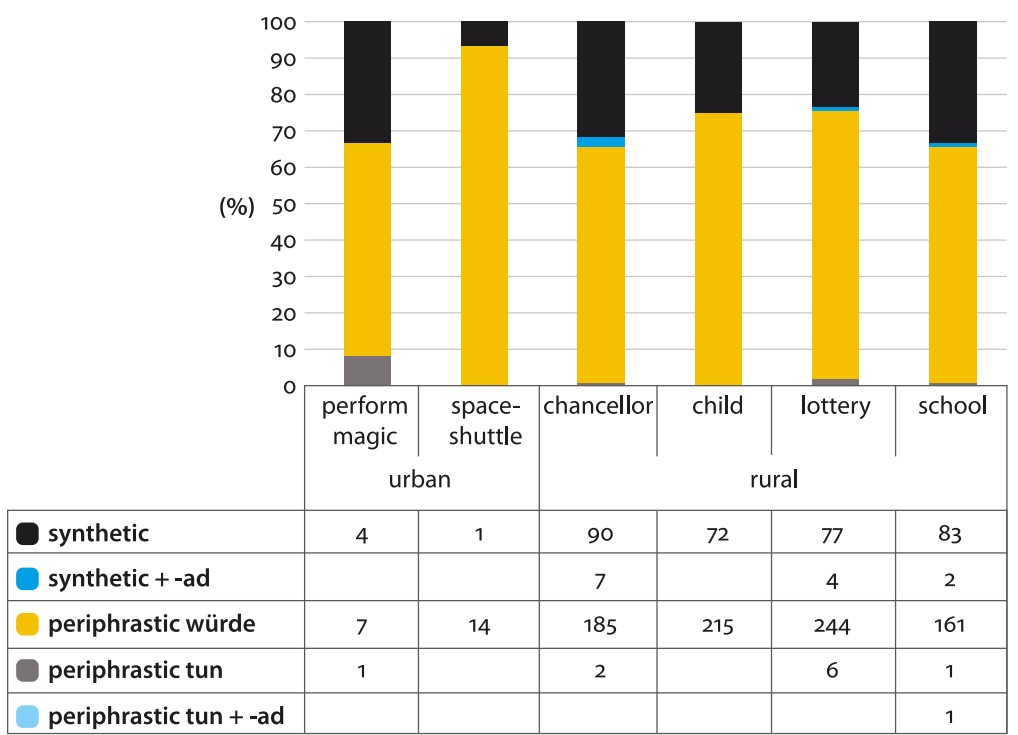

Figure 2. Frequencies of subjunctive II variants in the different tasks in LPE-s in the urban and the rural study (absolute numbers)

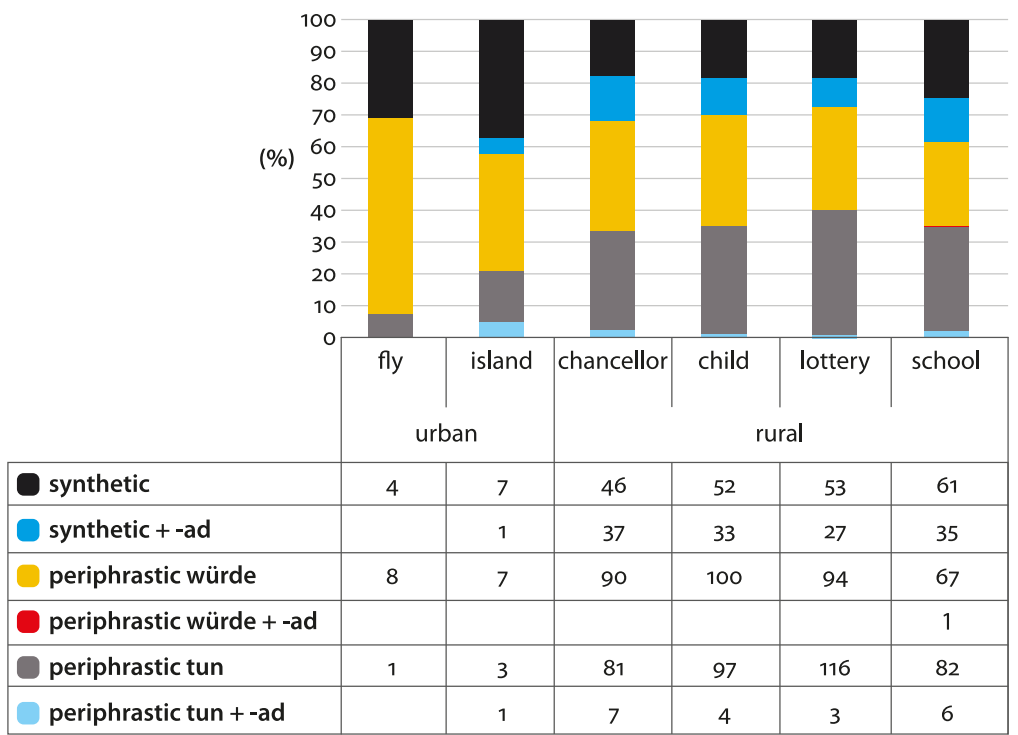

Figure 3. Frequencies of subjunctive II variants in the different tasks in the LPE-d in the urban and the rural study (absolute numbers) 
The absence of synthetic subjunctive II forms containing tun as a main verb, and the comparatively rare usage of periphrastic forms with tun, lead to the conclusion that the question in the stimuli from the urban study does not seem to have a considerable effect in terms of tending towards a rising of variants with tun (as one may claim because of the question Was tun Sie? 'What do you do?'). All tasks in the LPE-s (Figure 2) elicit similar answers - the preferred subjunctive II variant is consistently the würde-periphrasis, followed by synthetic subjunctive II forms conforming to the standard norm. In the LPE-d (Figure 3), we find more variation. Nevertheless, the picture is still similar; in most scenario descriptions the würde-subjunctive is dominant (exceptions are the lottery and the school tasks) followed by periphrasis with tun and synthetic forms corresponding to the standard norm. Subjunctive II forms with the ad-marker play a subordinate role in all tasks, though particularly in the tasks 'fly' and 'island', which came into use in the urban Vienna. These parallels indicate the validity and replicability of the LPEs conducted. The minor visible differences in Figure 2 and Figure 3 can be traced back to the different verbs chosen in the single tasks. As indicated in Figure 4, the conjugation (irregular versus regular) seems to influence the choice of variant. In our data, irregular verbs appear slightly more frequent in synthetic subjunctive constructions than regular verbs, independently of the variety. These results can be explained by the unambiguous subjunctive II form of (most) irregular verbs and do correspond to the literature (see e.g. Wiesinger 1989:56).

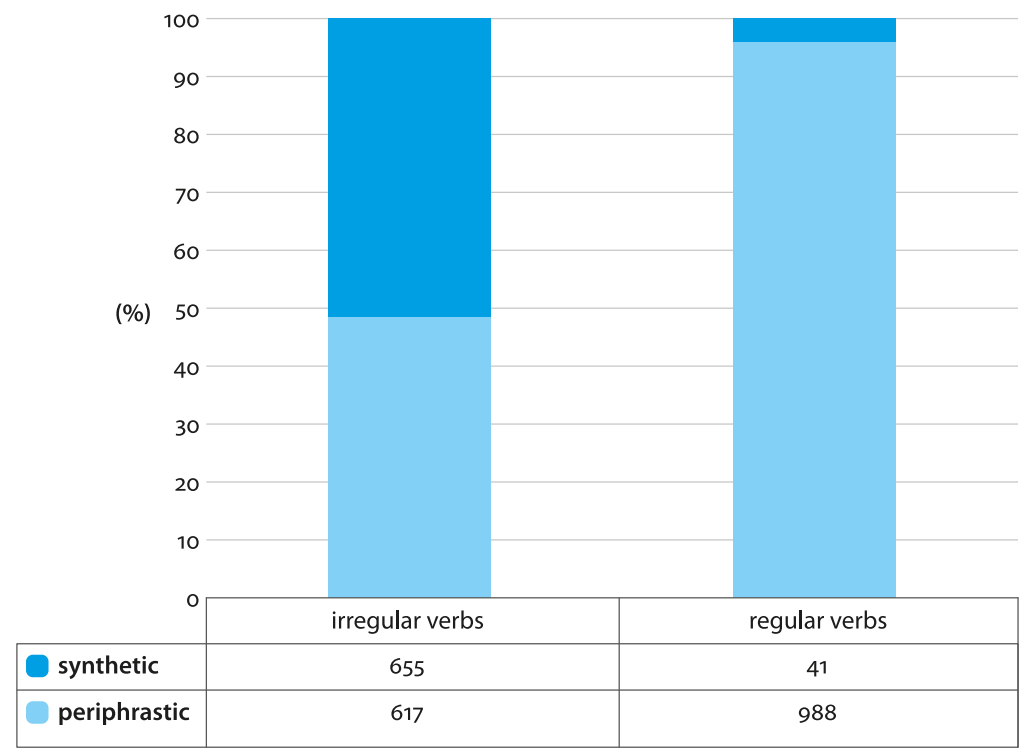

Figure 4. Frequencies of synthetic and periphrastic subjunctive II constructions with irregular and regular verbs in LPE-s and LPE-d in all research locations (absolute numbers) 
The high percentage of elicitations on point, and the general consistency with previous findings, indicate the adequacy of the LPEs for the investigation of the subjunctive II.

\subsection{Areal-horizontal variation}

In the following segment of analysis, we focus on the areal distribution of the different subjunctive II variants across the urban and rural research locations. The analyses ask for areal patterns of variation and a potential influence of the urban center Vienna on the surrounding regions, as it is suggested by e.g. Wiesinger (1992). Figure 5 and Figure 6 visualize the results of the two runs of the LPE and show the frequencies of the variants of subjunctive II in the research locations that are ordered by their distance to Vienna (in kilometers (rounded)).

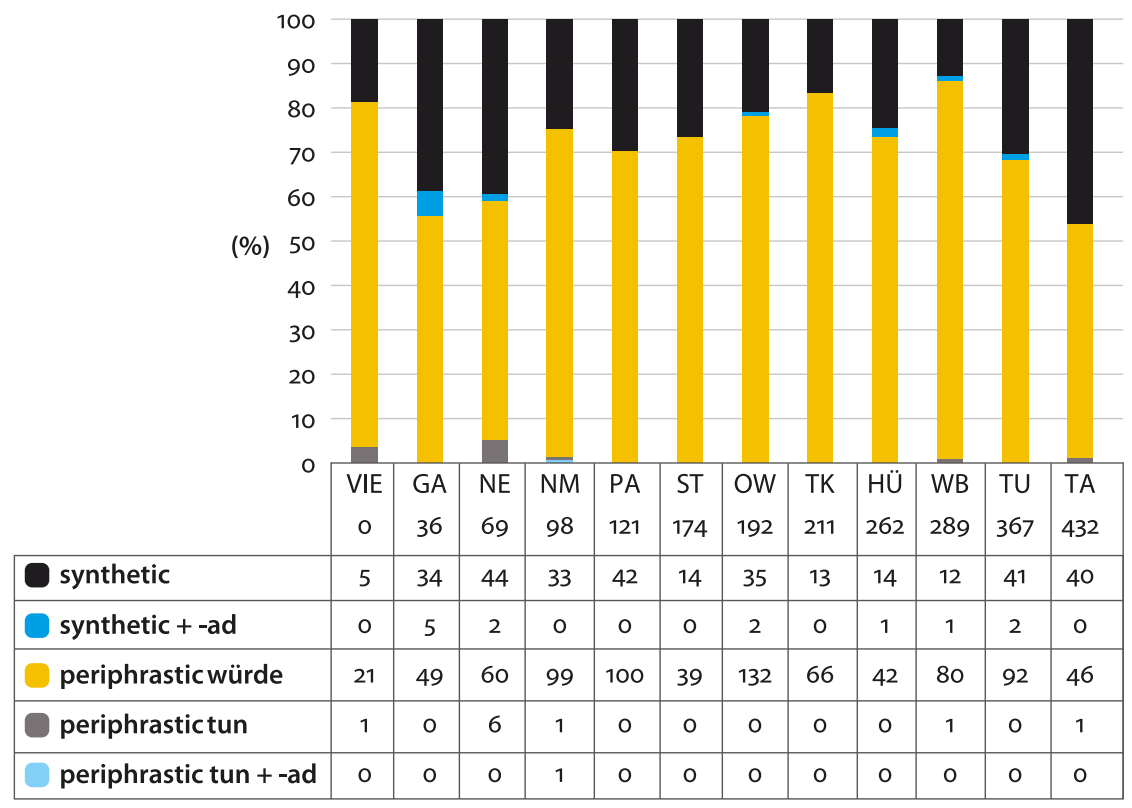

Figure 5. Frequencies of Subjunctive II variants in the different research locations in LPE-s, ordered by the distance in $\mathrm{km}$ (rounded) to Vienna (absolute numbers)

A first striking finding is the high number of competing subjunctive II variants in all research locations in the LPE-s (Figure 5) and especially in the LPE-d (Figure 6). Focusing on the LPE-s in Figure 5, mainly parallels between the single locations become visible in that there is one primary strategy of building a subjunctive II. In the urban as well as the rural regions, the periphrasis with würde is, as expected (see Section 3), the dominant variant, followed by synthetic construc- 


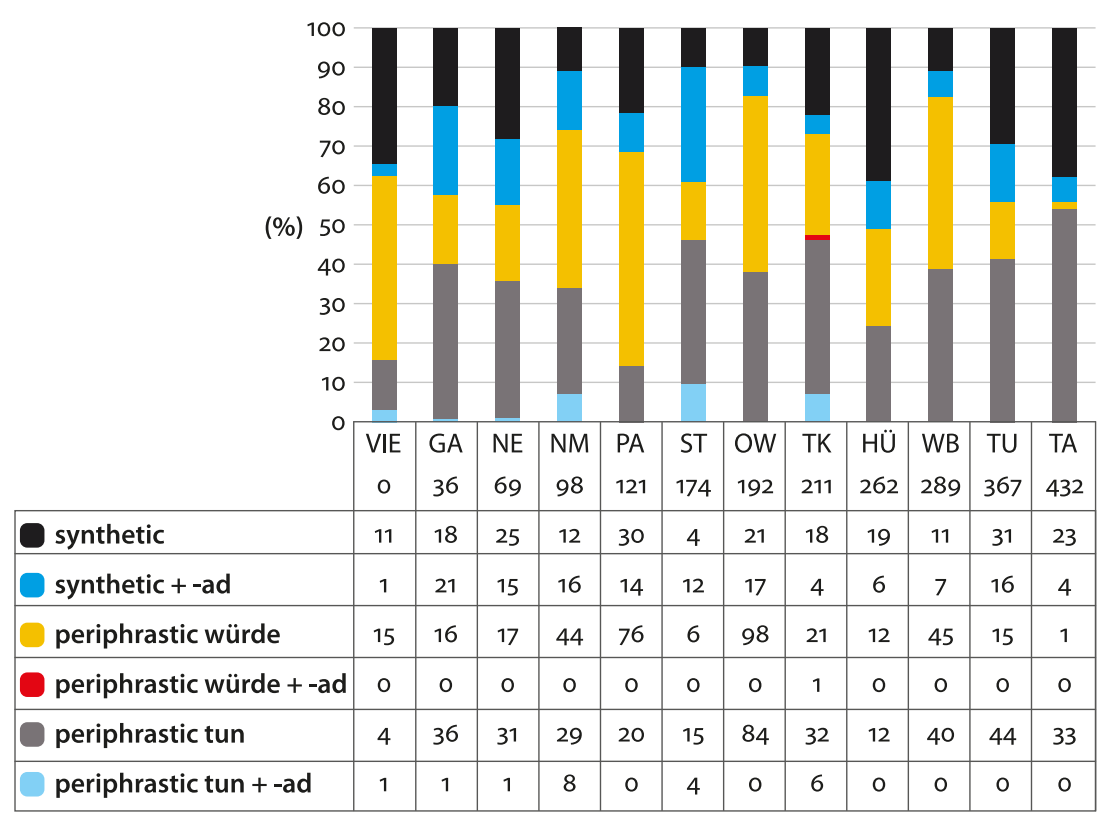

Figure 6. Frequencies of subjunctive II variants in the different research locations in LPE-d, ordered by the distance in $\mathrm{km}$ (rounded) to Vienna (absolute numbers)

tions. Other variants only appear rarely. In the LPE-d, displayed in Figure 6, more interregional variation is visible. As shown in Figure 6, an aspect that all the locations share is that a periphrasis is the preferred strategy to express the subjunctive II. The auxiliary is a varying factor. Approximately half of the research locations prefer tun (Gaweinstal, Neckenmarkt, Steyrling, Taufkirchen/Pram, Hüttschlag, Tux, Tarrenz), whereas the remaining locations (Vienna, Neumarkt/Ybbs, Passail, Oberwölz, Hüttschlag, Weißbriach) favor würde. Furthermore, we have found a variant that seems to be more restricted in its regional scope: the hybrid forms appear only in some locations (Vienna, Gaweinstal, Neckenmarkt, Neumarkt/Ybbs, Steyrling and Taufkirchen/Pram).

Despite these interregional parallels and differences, the LPE-s (Figure 5) and the LPE-d (Figure 6) do not provide support for the hypothesis that the urban Vienna has a grammatical influence on surrounding areas, at least concerning the phenomenon subjunctive II. ${ }^{12}$ Against the assumption that a big city as Vienna

12. We did not only test Vienna's impact based on the distance in kilometers to the rural research locations, but also sorted the locations by the journey time to Vienna by means of public transport with very similar results and no visible effects of the capital. Following e.g. Trudgill (1983) and Wiesinger (1992), we assume an influence of cities on neighboring regions. We are aware that by reducing this influence on merely geographical distance, we cast aside much of 
exerts an influence on neighboring areas, we observe neither a decline nor an increase of any structure with Vienna as starting point.

Whereas the interregional differences between the single research locations seem to be unsystematic and random in Figure 6, patterns become visible when changing perspective. In Figure 7 and Figure 8, the individual rural research locations are combined by their dialectal region, Vienna is displayed separately. Again, the LPE-s present a similar picture in Figure 7. The most pronounced differences occur between the Alemannic/Bavarian and the South Bavarian region. Whereas the Alemannic/Bavarian region is characterized by a comparatively high percentage of synthetic constructions, South Bavarian is the region with the lowest number of synthetic subjunctives and therefore the region with the most subjunctive II-periphrasis.

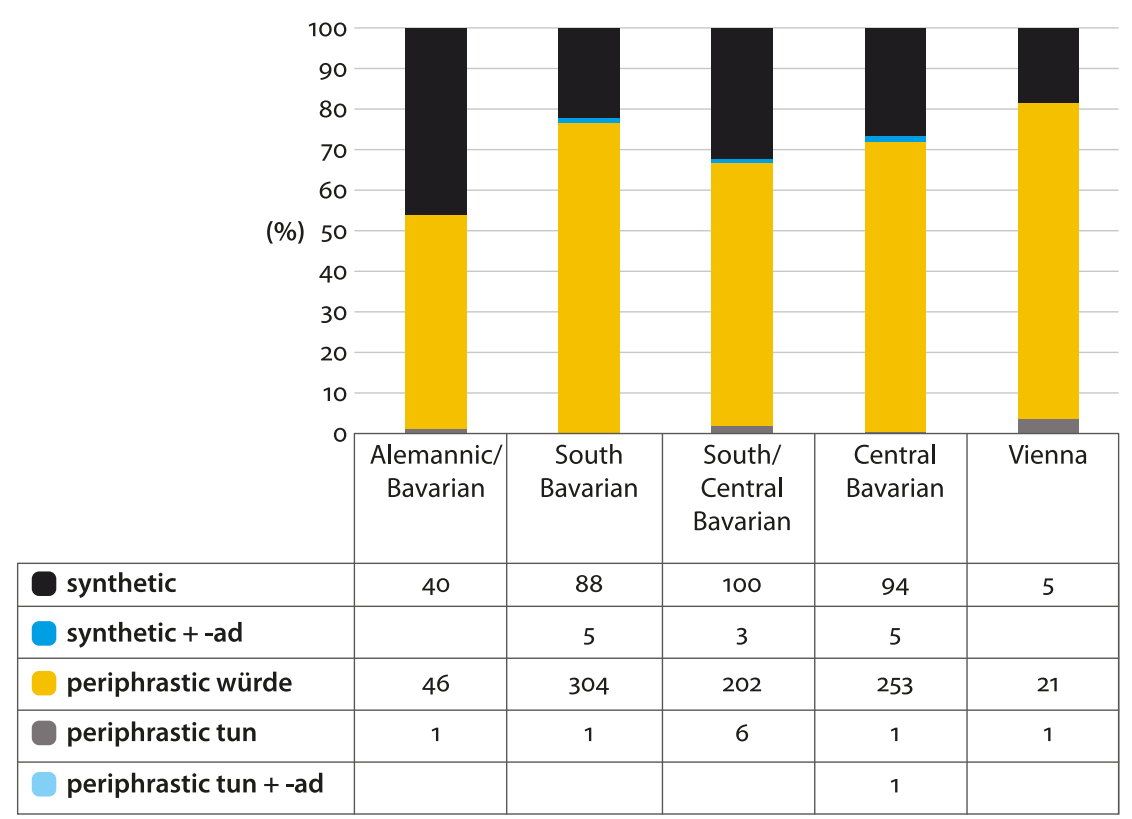

Figure 7. Frequencies of subjunctive II variants in LPE-s by dialect areas (absolute numbers)

The data from the LPE-d shown in Figure 8 illustrate that some of the observed variation in the individual locations corresponds to greater regional patterns. Our data indicate that the -ad marking on the auxiliary (mainly the auxiliary tun and in exceptional cases würde) appears almost exclusively in the Central Bavarian area but not in the entire Bavarian dialect area, even though the

the complexity and multifactoriality that may explain such an influence. Testing the distance and travel time to Vienna are just attempts at operationalization. 


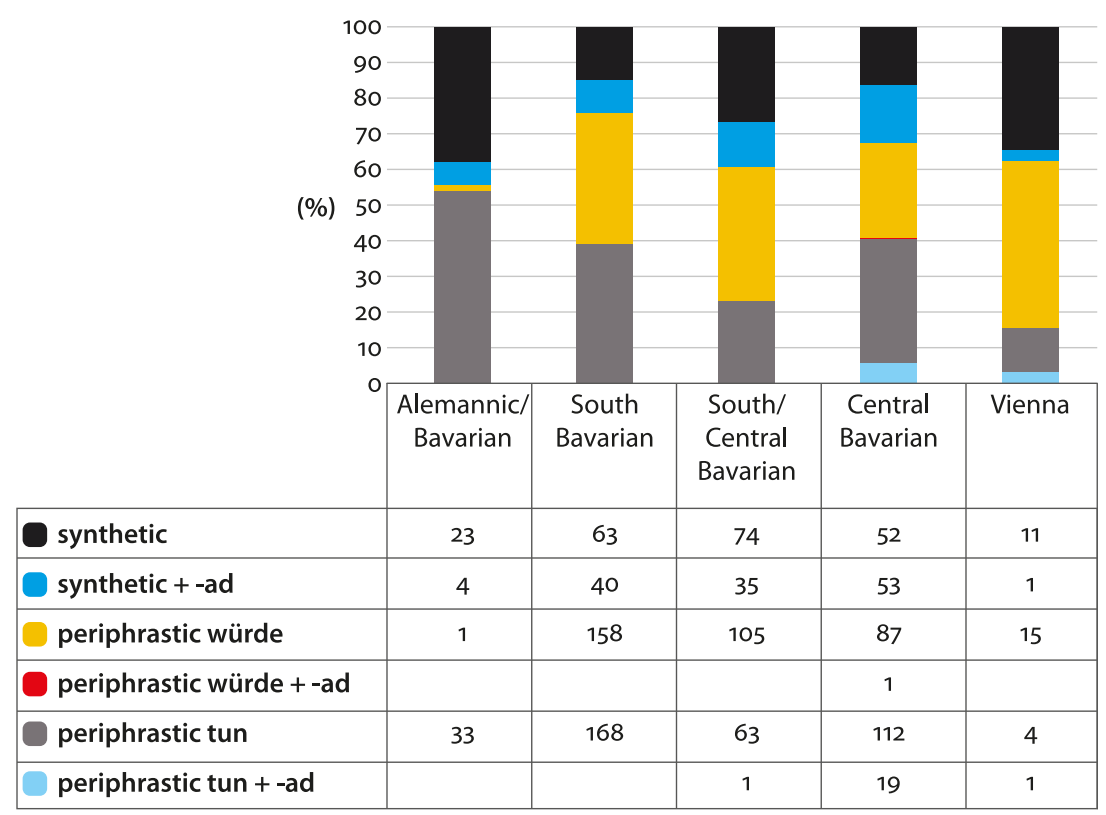

Figure 8. Frequencies of subjunctive II variants in LPE-d by dialect areas (absolute numbers)

ad-marker is common there. Additionally, Central Bavarian is the dialect region with the highest frequency of synthetic subjunctives with $-a d .{ }^{13}$ Concerning the ad-subjunctive, we see a decline towards the Alemannic/Bavarian region, where the construction is not common. In the Alemannic/Bavarian transition area, the $a d$-marker is still present albeit at a lower frequency compared to the Bavarian regions. The distribution of the two periphrastic subjunctive II forms on the dialect regions is noteworthy as well. Apart from South Central Bavarian, where the würde-subjunctive surpasses the tun-subjunctive, the subjunctive II with the tun-auxiliary is the dominant periphrastic variant.

To validate our observations, we performed statistical analyses and applied generalized linear mixed-effects models to our data, asking for the occurrence of different subjunctive II variants in dependence of the different stimuli, age group and region. ${ }^{14}$ The statistical analysis revealed significantly more periphrastic subjunctive II forms in the South Bavarian area $(\beta=1.1841, S E=0.5044, z=2.347$,

13. As the frequency of the variant combining a stem with an ablaut and the ad-marker is very low, we do not designate them a separate category. All subjunctives containing the ad-marker, regardless of their stem, are subsumed under the category 'synthetic +- ad'. We proceeded accordingly for the dialect variant with ablaut. As it occurs only rarely, we did not designate it a separate category but included it in the category of synthetic subjunctive II forms.

14. Statistical analyses are just provided where rated as increased knowledge. 
$p=0.0189)$ and a trend towards periphrastic subjunctive II constructions in Central Bavarian which is not significant $(\beta=0.9137, S E=0.4916, z=1.859, p=0.0631$ ). No significant urban/rural difference could be found. Furthermore, the model shows slightly significantly more würde-subjunctives than other constructions in Central Bavarian $(\beta=1.3086, S E=0.6084, z=2.151, p=0.03150)$ and the South/ Central Bavarian transition zone $(\beta=1.3671, S E=0.6211, z=2.201, p=0.02773)$ and a medium effect in South Bavarian $(\beta=1.9181, S E=0.6147, z=3.121, p=0.00181)$. Concerning the $a d$-variant, we could find a non-significant trend towards more $a d$-subjunctive II forms in Central Bavarian $(\beta=1.1886, z=0.6746, S E=1.7620$, $p=0.078084$ ).

As our sociodemographically heterogenous data, collected by the means of LPEs, allows us to explore the area-horizontal variation as well as vertical variation and even dynamics, we will now take a look at the interindividual and intersituative distribution of subjunctive II variants.

\subsection{Intergenerational variation}

Figure 9 and Figure 10 are contrasting the two groups of informants and reveal striking differences between the older and the younger generation in the urban and the rural data. The Figures $(9 \& 10)$ indicate that, in urban as well as in rural areas, younger speakers tend to use more periphrastic than synthetic subjunctive II forms. Based on an apparent time approach, these findings can be interpreted as trending towards the decline of synthetic forms in favor of periphrastic ones. Applying Fisher's Exact Test supports the observation that younger speakers use more subjunctive periphrasis (with würde and tun) compared to synthetic forms than older speakers in our data from rural locations in both runs of the LPE (LPE-s: $p<2.2 \mathrm{e}-16$, LPE-d: $p<2.2 \mathrm{e}-16$ ). Additionally, the würde-periphrasis occurs significantly more frequently (in comparison to other synthetic forms and the subjunctive with tun) among the younger generation than the older generation, again in both runs of the LPE (LPE-s: $p<2.2 \mathrm{e}-16$, LPE-d: $p<2.2 \mathrm{e}-16$ ).

Urban speakers also show a preference for periphrasis, which fits into the description of cities as highly dynamic language areas that have a tendency towards new and productive forms (see Section 3 and Dingeldein 2002: 22). However, again applying the Fisher's Exact Test, comparing younger speakers from urban and rural locations, there is no indication that the tendency towards periphrastic forms is stronger in the urban speakers, urbanity vs. rurality in contrast to speaker generation. It therefore does not appear as a factor that influences the use of periphrastic subjunctive II forms.

Nevertheless, the synthetic forms are still relatively persistent at least for old rural speakers, which are the group with the highest frequencies of synthetic con- 
structions in LPE-s and LPE-d. In this regard, old Viennese speakers appear to use variants more dynamically depending on the situation.

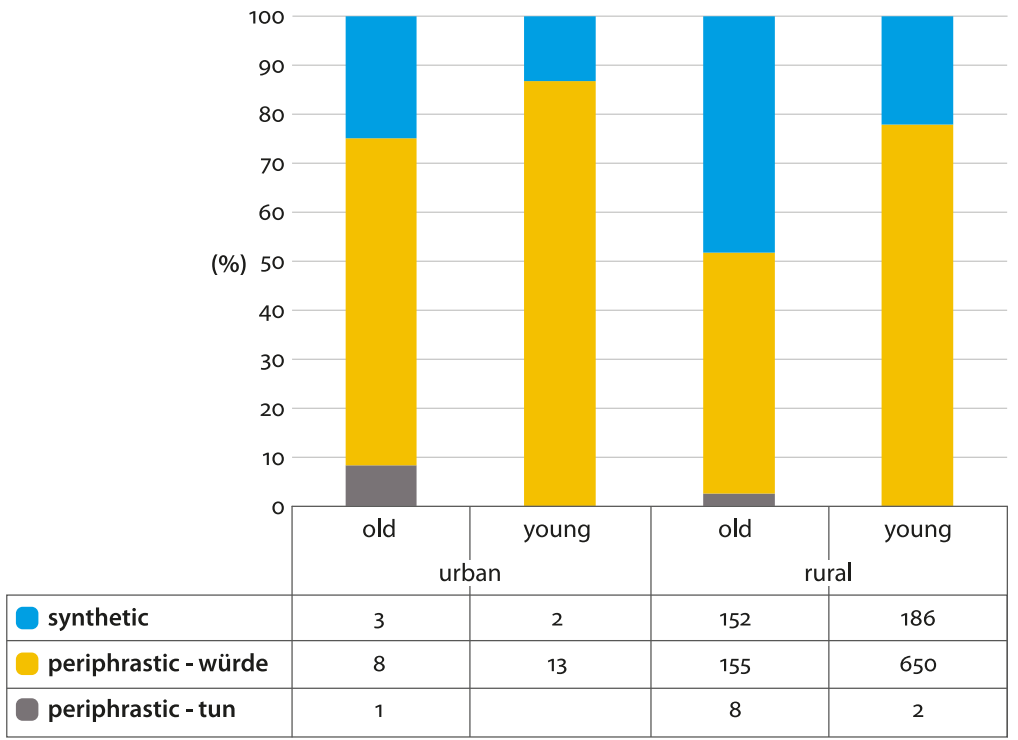

Figure 9. Frequencies of synthetic and periphrastic subjunctive II forms in LPE-s urban versus rural (absolute numbers)

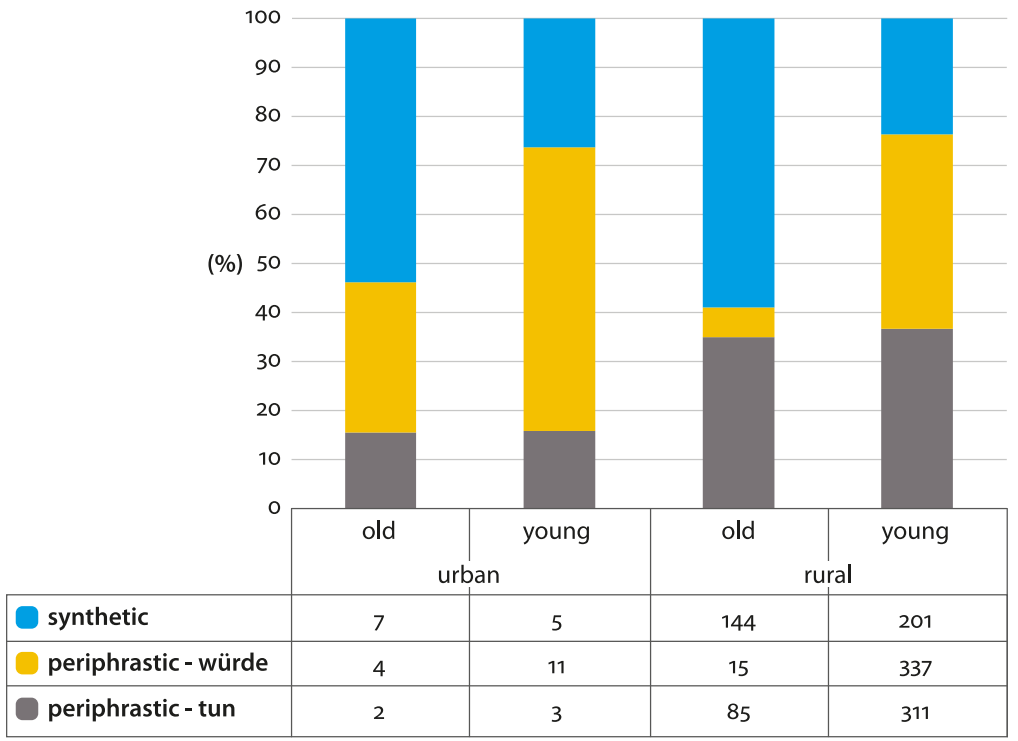

Figure 10. Frequencies of synthetic and periphrastic subjunctive II forms in LPE-d urban versus rural (absolute numbers) 


\subsection{Intersituative variation}

The discussion in the previous section indicated intersituational variation. These differences, as well as parallels, become apparent when contrasting the LPE-s and the LPE-d run (Figure 11) separately for the urban research location Vienna and the rural ones. Figure 11 reveals striking intersituative differences. In the LPE-s, almost exclusively variants conforming to the standard norm (würde-subjunctive and synthetic constructions corresponding to the - at least morphosyntactical (but not necessarily phonetical) standard norm) occur. Other variants (see also Table 3) do not seem to be associated with registers closer to the standard. These findings are valid for the urban, and rural areas that are uniform regarding the participant's best / formal standard (see Section 5). A major difference between the two runs is in the choice of auxiliary. In the LPE-s, the subjunctive II formed with würde is the dominant periphrasis (and even variant) in rural as well as in urban areas, in the LPE-d, a contrast between urban and rural research locations becomes apparent. With a percentage of $34.4 \%$ (tun-subjunctive II) and $32.1 \%$ (würde-subjunctive II) of all answers given by the rural participants, the two periphrasis display the preferred variants. In contrast, the urban informants mainly answer with a periphrasis containing würde (46.8\%) and even synthetic subjunctive II constructions corresponding to the norm standard form are more frequent among Viennese than constructions with tun, which are used third most (12.5\%). The diagram indicates that, among the periphrastic forms, the construction with würde is spreading and is used in lower registers, as it is even used in LPE-d to a considerable extent (see Figure 11). Therefore, würde does not only spread geographically and is increasingly used among the younger generation, but spreads wider in all varieties, making it a potential default variant for at least periphrastic subjunctive forms. Nevertheless, we still find highly significant less würde-subjunctives in LPE-d compared to the LPE-s $(\beta=-10.621, S E=1.044$, $z=-10.171, p=<2 \mathrm{e}-16)$.

These insights into the interindividual variation suggest that the urban area varies more, considering the comparison between periphrastic and synthetic forms. The intersituational view reveals that the rural area has a more balanced ratio between different lexical and morphological variants for building subjunctive II. This implies a stronger parallel existence of different variants, what can be described as a highly dynamic as well. This shows an exciting, complex variation pattern concerning subjunctive II forms in Austria for the whole dialect-standardspectrum.

Furthermore, the high number of standard-conform variants in the LPE-s, and the major restriction of variants described for varieties closer to the dialect in 


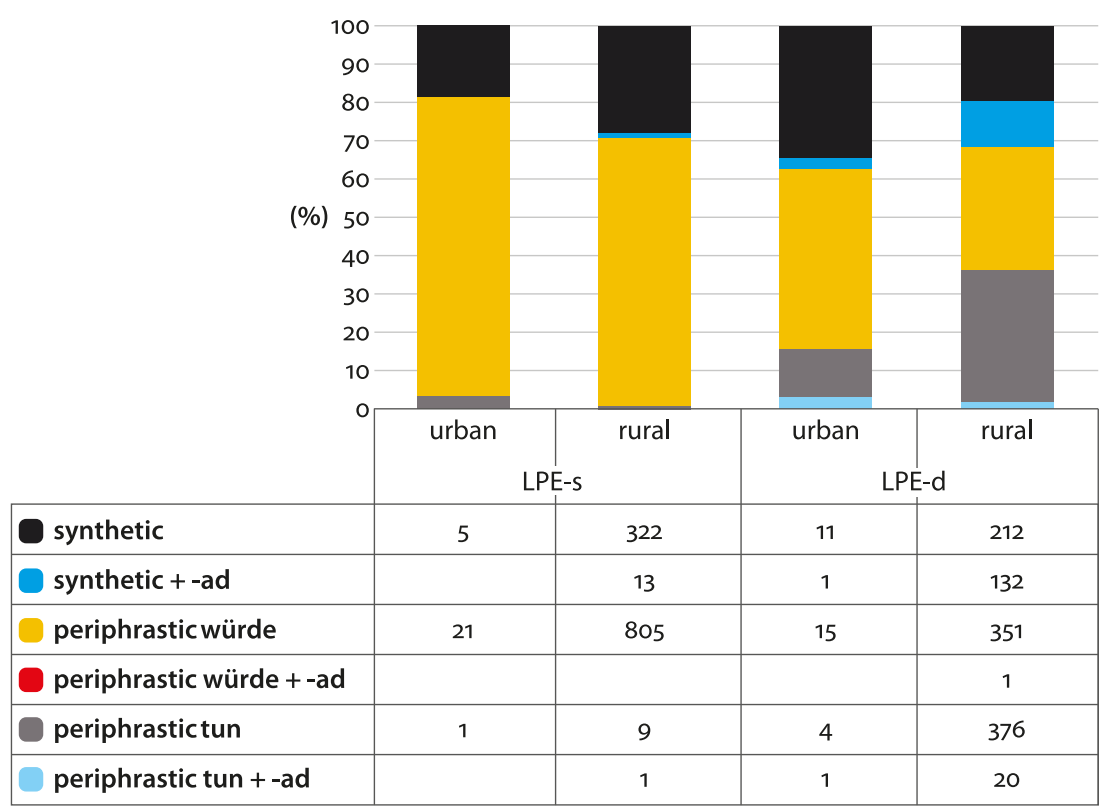

Figure 11. Frequencies of subjunctive II variants in LPE-s vs. LPE-d in urban and rural research locations (absolute numbers)

LPE-d, indicate the success of the method to elicit data of the intended varieties each (see Section $4 \& 5$ ).

\section{Conclusion}

The primary goal of this paper was to cover a niche by firstly investigating arealhorizontal but also social-vertical morphosyntactic variation of subjunctive II in urban and rural areas in Austria in contrast. Our spoken data from 12 research locations in Austria show that the subjunctive II is a highly variable phenomenon. This is interesting from a morphological and syntactical point of view, due to the synthetic and periphrastic strategies that are available for the formation of the subjunctive II. The corpus consists of data collected using the innovative method of Language Production Experiments.

Going back to the initial research questions (Section 1), our findings show that our LPEs successfully elicited subjunctive II constructions, and that conducting them in different runs which target speakers' dialect and Standard German in different research locations allows for fruitful analyses of variation on the horizontal and vertical axis. The high degree of comparability of our data between the two studies, and the richness of elicited subjunctive II-variants, speak 
for the success and reliability of the elicitation method (see research question 1). Nonetheless, the comparability would have been higher if both studies had used the same set of stimuli in all experimental runs - this limitation is owed to the basic research character of the two separate studies (see Section $5 \&$ footnote 12)

However, beyond these methodological findings, the study provides new insights into the areal-horizontal distribution (research question 2) of the subjunctive II variants across the Austrian language space, where we find superregional subjunctive II variants (the würde-subjunctive, the standard-conform synthetic subjunctive II constructions) as well as variants that appear to only be used regionally (e.g. the ad-marker on the auxiliary as well as the main verb). From a synchronic point of view, our data do not support the hypothesis of an influence of the city of Vienna on neighboring locations, with respect to the analyzed phenomenon subjunctive II. At the same time, our data provide evidence for areal patterns with a more decisive influence of the dialect region. This influence of the dialect region becomes visible when focusing on the hybrid forms, combining a subjunctive auxiliary with the ad-marker, which occurs in all research locations in Central Bavarian whilst all other regions (with the exception of a single occurrence in South/Central Bavarian) lack this variant. These findings lead to us to expect to find similar patterns of the distribution of variants in other corpora for the same semantical (and syntactical) context, or respectively for other locations in the observed areas. Since the influence of the (urban) Vienna could not be attested for this variable, we predict that this influence will not be a vital parameter for rural regional varieties.

Concerning the third research question, asking for the interindividual distribution of subjunctive II variants among different groups of speakers, we found regardless of the research location - a global tendency towards the decline of all synthetic subjunctive II constructions in the younger speaker generation. Periphrastic constructions, however, show an increase (in different lexical forms) in both runs of the LPE. In terms of the Apparent-Time-Hypothesis, the comparison of the data of the older generation with the younger generation reveals ongoing processes of change and shows that among the periphrastic subjunctive II forms especially the würde-periphrasis is spreading.

These findings correspond to the results of the intersituative analyses (see research question 4) that contrast the two runs of the LPE. We found the würde-subjunctive extending its domain - varieties closer to the standard - and moving into registers closer to the dialect. Besides this further intersituative differences become apparent, these difference are expressed by run-specific variants (e.g. ad-subjunctive II) on the one hand, by varying frequencies of variants that occur in both runs of the LPE (e.g. würde-subjunctive II, synthetic forms corresponding to the standard norm), on the other hand. 
Aside from the variation dimensions focused in the article, the LPEs are designed in a way that allows us to gain insights into the intra-individual variation (see e.g. Breuer/Bülow 2019; Lenz et al. 2019). These detailed analyses of patterns of intra-speaker variation would extend the scope of the paper, which focuses on a more comprehensive overview of subjunctive II variants in Austria and addresses especially urban-rural-differences, as well as on the methodological approach. Nevertheless, intraspeaker variation of subjunctive II is particularly promising, as the empirical findings in Section 5 (especially on the intersituative variation) indicate that the subjunctive II is a variable with diverse variants coexisting in the repertoire of one and the same individual, and should therefore be considered in future research.

Our article could demonstrate the potential of LPEs to investigate grammatical phenomena on the horizontal and vertical axis. As the setup of the LPE and the interaction with a computer may be considered 'unnatural', the data presented here leaves the question regarding which variants speakers use in more everyday conversational settings. Moreover, owed to practical reasons (the amount of single tasks in one LPE run, also see Section 5) the data are limited to the semantical field of irrealis/potentialis of the subjunctive II variable, while other semantical usages could lead to other distribution of variants. Both limitations (artificial survey setting, restrictions concerning the semantical field of subjunctive II) do not apply to the extended urban and rural corpora, which also includes free conversational data and therefore a lesser controlled setting. This extended corpus, as well as the repeatability of the experimental settings, leads us to consider further research.

\section{Funding}

Research funded by Austrian Science Fund (F6o, F6003, F6011).

\section{Acknowledgements}

The present study on rural data is based on surveys conducted in the project part 03 (ppo3) 'Speech repertoires and varietal spectra' (FWF Fo6003, principal investigator: Alexandra N. Lenz, see https://dioe.at/projekte/task-cluster-b-variation/ppo3/) of the Special Research Programme 'German in Austria. Variation - Contact - Perception' (DiÖ) (FWF F6o, project leader: Alexandra N. Lenz). The authors are grateful to the Austrian Science Fund (FWF) for funding this project. On the other hand, the study on urban data is part of a dissertation project focusing the vertical (morpho-)syntactic variation in modern Viennese between and includ- 
ing the poles Viennese Dialect and Viennese Standard German (for a detailed description see Breuer 2017a).

Special thanks are due to Matthias Fingerhuth, Manfred M. Glauninger, Pamela Goryczka, Katharina Korecky-Kröll, Alexandra N. Lenz and Philipp Stöckle for their support. And as always, many thanks to Peter Ernst and Franz Patocka.

\section{References}

Abraham, Werner \& Annette Fischer. 1998. Das grammatische Optimalisierungsszenario von tun als Hilfsverb. In Karin Donhauser \& Ludwig M. Eichinger (eds.), Deutsche Grammatik. Thema in Variationen. Festschrift für Hans-Werner Eroms zum 60. Geburtstag. (Germanistische Bibliothek), vol. 1, 35-47. Heidelberg: Winter.

Auer, Anita. 2007. Österreichisches Deutsch ist eine würde-volle Sprache - The Subjunctive Mood in Eighteenth-Century Austria. Leiden Working Papers in Linguistics 4(1). 1-20.

Auer, Anita \& Anja Voeste. 2012. Grammatical Variables. In Juan Manuel Hernández Campoy \& Juan Camilo Conde-Silvestre (eds.), The handbook of historical sociolinguistics, 253-270. Malden, MA: John Wiley and Sons. https://doi.org/10.1002/9781118257227.ch14

Auer, Peter. 2005. Europe's sociolinguistic unity, or: A typology of European dialect/standard constellations. In Nicole Delbecque, Johan van der Auwera \& Dirk Geeraerts (eds.), Perspectives on variation. Sociolinguistic, historical, comparative, 69-92. Berlin: de Gruyter. https://doi.org/10.1515/9783110909579.7

Barbiers, Sjef, Hans Bennis, Gunther De Vogelaer \& Margreet van der Ham. 2005. Syntactic Atlas of the Dutch Dialects. Volume 1. Amsterdam: Amsterdam University Press. https://doi.org/10.5117/9789053567005

Bellmann, Günter. 1983. Probleme des Substandards im Deutschen. In Klaus J. Mattheier (ed.), Aspekte der Dialektheorie, 105-130. Tübingen: Max Niemeyer. https://doi.org/10.1515/9783111371108.105

Bercko, Nina. 2018. Südmittelbairische Verbalflexion in alltagssprachlicher Verwendung im Stadt-Land-Vergleich. In Kirsten Adamzik \& Mateusz Maselko (eds.), VARIATIONslinguistik trifft TEXTlinguistik, 83-104. Europäische Studien zur Textlinguistik, 83-104. Tübingen: Narr.

Bittner, Andreas \& Klaus-Michael Köpcke. 2010. Ich würde, wenn ich wüsste, dass ich könnte...- Der Konjunktiv zwischen Synthese und Analyse. In Dagmar Bittner \& Livio Gaeta (eds.), Kodierungstechniken im Wandel. (Linguistik - Impulse \& Tendenzen), 23-46. Berlin \& New York: de Gruyter. https://doi.org/10.1515/9783110228458.23

Breuer, Ludwig M. 2016. Methoden städtischer Regionalsprachenforschung: Wiener Variation des Relativsatzanschlusses im Online-Fragebogen. In Alexandra N. Lenz \& Franz Patocka (eds.), Syntaktische Variation: Areallinguistische Perspektiven. (Wiener Arbeiten zur Linguistik), vol. 2, 219-248. Göttingen: Vienna University Press.

Breuer, Ludwig M. 2017a. Computers \& Coffee: Computergestützte Sprachproduktionstests zur syntaktischen Variation des ,unbestimmten Artikels vor Massennomen' im ,Wienerischen'. In Helmut Kowar (ed.), International Forum on Audio-Visual Research. (Jahrbuch des Phonogrammarchivs), vol. 7, 86-111. Wien: Verlag der Österreichischen Akademie der Wissenschaften. 
Breuer, Ludwig M. 2017b. Wien, das was anders ist? Relativsatz-Anschluss in einem spontansprachlichen „Wiener” Korpus. In Alexandra N. Lenz,

Ludwig Maximilian Breuer, Tim Kallenborn, Peter Ernst, Manfred Michael Glauninger \& Franz Patocka (eds.), Bayerisch-österreichische Varietäten zu Beginn des 21. Jahrhunderts Dynamik, Struktur, Funktion, 177-198. Stuttgart: Franz Steiner.

Breuer, Ludwig M. i. prep. Syntaktische Variation der modernen Regionalsprache in Wien. Doctorial Dissertation, University of Vienna.

Breuer, Ludwig M. \& Lars Bülow. 2019. Experimental approaches in the realm of language variation - How Language Production Tests can help us to better understand language variation. In Lars Bülow, Ann-Kathrin Fischer \& Kristina Herbert (eds.), Dimensionen des sprachlichen Raums. Variation - Mehrsprachigkeit - Konzeptualisierung, (Schriften zur deutschen Sprache in Österreich), vol. 45, 251-272. Frankfurt am Main et al.: Peter Lang Verlag.

Breuer, Ludwig M. \& Manfred M. Glauninger. 2012. Editorial. Tribüne - Zeitschrift für Sprache und Schreibung (1):2-3.

Brinckmann, Caren \& Noah Bubenhofer. 2012. Sagen kann man's schon, nur schreiben tut man's selten. Die tun-Periphrase. In Roman Schneider \& Marek Konopka (eds.), Grammatische Stolpersteine digital. Festschrift für Bruno Stecker zum 65. Geburtstag, 159. Mannheim: Institut für Deutsche Sprache.

Brooks, Thomas. 2015. Diese bedingungslose Liebe zu den Sprachfehlern ... Sprachgeografische Betrachtungen zur würde-Umschreibung am Beispiel Robert Musil. In Alexandra N. Lenz \& Manfred Michael Glauninger (eds.), Standarddeutsch im 21. Jahrhundert. Theoretische und empirische Ansätze mit einem Fokus auf Österreich, 237-250. Göttingen: V\&R unipress, Vienna University Press. https://doi.org/10.14220/9783737003377.237

Bucheli, Claudia \& Elvira Glaser. 2002. The Syntactic Atlas of Swiss German Dialects: empirical and methodological problems. In Sjef Barbiers, Leonie Cornips \& Susanne van der Kleij (eds.), Syntactic Microvariation, (Meertens Institute Electronic Publications in Linguistics), vol. II, Amsterdam: Meertens Institute. http://www.meertens .knaw.nl/books/synmic/

Budin, Gerhard, Stephan Elspaß, Alexandra N. Lenz, Stefan M. Newerkla \& Arne Ziegler. 2018. Der Spezialforschungsbereich „Deutsch in Österreich (DiÖ). Variation - Kontakt Perzeption“. Zeitschrift für germanistische Linguistik 46(2). 300-308. https://doi.org/10.1515/zgl-2018-0017

Chambers, Jack \& Peter Trudgill. 1998. Dialectology. 2nd edition. Cambridge: Cambridge UnivPress. https://doi.org/10.1017/CBO9780511805103

Cheshire, Jenny. 2005. Syntactic Variation and Beyond: Gender and Social Class Variation in the Use of Discourse-New Markers. Journal of Sociolinguistics 9(4). 479-508. https://doi.org/10.1111/j.1360-6441.2005.00303.x

Cheshire, Jenny, Paul Kerswill, Sue Fox \& Eivind Torgersen. 2011. Contact, the feature pool and the speech community: The emergence of Multicultural London English. Journal of Sociolinguistics 15(2). 151-196. https://doi.org/10.1111/j.1467-9841.2011.00478.x

Cornips, Leonie \& Cecilia Poletto. 2005. On standardising syntactic elicitation techniques (part 1). Lingua 115(7). 939-957. https://doi.org/10.1016/j.lingua.2003.11.004 
Dingeldein, Heinrich J. 2002. Methoden der Stadtsprachenforschung. In Zsuzsanna Gerner (ed.), Gesprochene und geschriebene deutsche Stadtsprachen in Südosteuropa und ihr Einfluss auf die regionalen deutschen Dialekte: Internationale Tagung in Pécs, 30.3.-2.4.200o, 21-38. Wien: Praesens.

Donhauser, Karin. 1992. Der Konjunktiv im Bairischen. Dialekte im Wandel. Referate der 4. Tagung zur Bayerisch-Österreichischen Dialektologie, Salzburg 5. bis 7. Oktober 1989. (Göppinger Arbeiten Zur Germanistik), vol. 538, 226-242. Göppingen: Kümmerle.

Duden. 2016. Die Grammatik. Unentbehrlich für richtiges Deutsch. 9th updated and revised edition. Mannheim et al.: Dudenverlag.

Eisenberg, Peter. 2013. Grundriss der deutschen Grammatik: Band 2: Der Satz. 4th updated and revised edition. Stuttgart et al.: Metzler.

Eroms, Hans-Werner. 1998. Periphrastic tun present-day Bavarian and other German dialects. In Ingrid Tieken-Boon van Ostade, Marijke van der Wal \& Arjan van Leuvensteijn (eds.), Do in English, Dutch and German. History and present-day variation, 139-157. Münster: Nodus-Publ.

Fabricius-Hansen, Cathrine. 200o. Die Geheimnisse der deutschen würde-Konstruktion. In Rolf Thieroff, Matthias Tamrat, Nanna Fuhrhop \& Oliver Teuber (eds.), Deutsche Grammatik in Theorie und Praxis, 83-96. Tübingen: Max Niemeyer. https://doi.org/10.1515/9783110933932.83

Fanta-Jende, Johanna. i.p. Varieties in Contact. The case of MHG /ei/ in Austria. In Alexandra N. Lenz \& Mateusz Maselko (eds.), Variationist Linguistics meets Contact Linguistics. Vienna: Vienna University Press.

Fingerhuth, Matthias \& Ludwig M. Breuer. accepted. How Much Method is in the Data? A Contrastive Study of Complementizer Agreement and Doubly-Filled Comp Elicited through Translation Tasks and Language Production Experiments. To appear in International Journal of Corpus Linguistics.

Fingerhuth, Matthias \& Alexandra N. Lenz. i.p. Variation and Change of "Complementizer Agreement" in German. Analyses from the Austrian language area. To appear in Linguistic Variation.

Fleischer, Jürg, Alexandra N. Lenz \& Helmut Weiß. 2017. SyHD-atlas. Conceived by Ludwig M. Breuer. Assisted by Katrin Kuhmichel, Stephanie Leser-Cronau, Johanna Schwalm und Thomas Strobel. Marburg/Wien/Frankfurt am Main: https://doi.org/10.17192/es2017.0003

Glauninger, Manfred M. 2008. Synthetische und analytische „Konjunktiv 2“ - Formen im Wiener Nonstandard-Deutsch. In Franz Patocka \& Guido Seiler (eds.), Dialektale Morphologie, dialektale Syntax, 233-247. Wien: Praesens.

Glauninger, Manfred M. 2010. Zwischen Hochdeutsch, Dialekt und Denglisch. „Innere Mehrsprachigkeit" und urbane Kommunikation am Beispiel der Jugendlichen im Ballungsraum Wien. In Adalbert Stifter-Institut des Landes Oberösterreich \& Oberösterreichisches Volksliedwerk (eds.), Übergang: Kommunikation in der Stadt und an ihren Rändern, 181-193. Linz: StifterHaus - Zentrum für Literatur und Sprache in OÖ \& Oberösterr. Volksliedwerk.

Glauninger, Manfred M. 2011. Zum honorativen Konjunktiv 2 als Modalisierungsoption. Aspekte einer funktionalen Typologie des Wiener Deutsch. In Helen Christen, Franz Patocka \& Evelyn Ziegler (eds.), Struktur, Gebrauch und Wahrnehmung von Dialekt: Beiträge zum 3. Kongress der Internationalen Gesellschaft für Dialektologie des Deutschen (IGDD), Zürich, 7.-9. September 2009, 47-57. Wien: Praesens. 
Glinz, Hans. 1994. Grammatiken im Vergleich: Deutsch, Französisch, Englisch, Latein; Formen, Bedeutungen, Verstehen; [Studienbuch] (Reihe Germanistische Linguistik; 136:

Kollegbuch). Tübingen: Niemeyer. https://doi.org/10.1515/9783110914801

Hasty, Daniel J. 2014. We might should be thinking this way. Theory and Practive in the Study of Syntactic Variation. In Raffaella Zanuttini \& Laurence R. Horn (eds.), Micro-Syntactic Variation in North American English, 269-293. Oxford et al.: Oxford University Press. https://doi.org/10.1093/acprof:oso/9780199367221.003.0009

Hornung, Maria \& Sigmar Grüner. 2002. Wörterbuch der Wiener Mundart. 2nd extended and revised edition. Wien: öbv \& hpt.

Kallenborn, Tim. 2016. Regionalsprachliche Syntax: Horizontal-vertikale Variation im Moselfränkischen. Wien: Doctorial Dissertation, University of Vienna.

Koppensteiner, Wolfgang \& Alexandra N. Lenz. 2017. Theoretische und methodische Herausforderungen einer perzeptiv-attitudinalen Standardsprachforschung. Perspektiven aus und auf Österreich. In Heinz Sieburg \& Hans-Werner Solms (eds.), Das Deutsche als plurizentrische Sprache. Ansprüche - Ergebnisse - Perspektiven (Zeitschrift für deutsche Philologie Sonderheft), 43-68. Berlin: Erich Schmidt.

Korecky-Kröll, Katharina. accepted. Morphological dynamics of German adjective gradation in rural regions of Austria. To appear in Zeitschrift für Linguistik und Dialektologie.

Kortmann, Bernd. 2010. Areale Variation in Syntax. In Peter Auer \& Schmidt Jürgen Erich (eds.), Language and Space, vol. I: Theories and Methods, 837-864. Berlin: de Gruyter.

Kristiansen, Tore. 2010. Investigating Language in Space: Experimental Techniques. In Peter Auer \& Jürgen E. Schmidt (eds.), Handbooks of Linguistics and Communication Science: Vol. 30.1. Language and Space. An international Handbook of Linguistic Variation. Volume 1: Theories and Methods, 528-549. Berlin: de Gruyter.

Labov, William. 1975. What is a linguistic fact? Lisse: de Ridder. https://doi.org/10.1515/9783110882353

Labov, William. 1978. Crossing the Gulf between Sociology and Linguistics. The American Sociologist 13(2). 93-103.

Langer, Nils. 2001. Linguistic purism in action: How auxiliary tun was stigmatized in Early New High German. Berlin \& New York: de Gruyter. https://doi.org/10.1515/9783110881103

Lavandera, Beatriz R. 1978. Where Does the Sociolinguistic Variable Stop? Language in Society 7. 171-82. https://doi.org/10.1017/So047404500005510

Lenz, Alexandra N. 2003. Struktur und Dynamik des Substandards: eine Studie zum Westmitteldeutschen (Wittlich/Eifel) (Zeitschrift für Dialektologie und Linguistik: Beihefte 125). Stuttgart: Steiner.

Lenz, Alexandra N. 2010. Emergence of Varieties through Restructuring and Reevaluation. In Peter Auer \& Jürgen Erich Schmidt (eds.), Language and Space. An International Handbook of Linguistic Variation. Volume 1: Theories and Methods, 295-315. Berlin \& New York: de Gruyter Mouton.

Lenz, Alexandra N. 2016. On eliciting dialect-syntactic data. Comparing direct and indirect methods. In Augustin Speyer \& Philipp Rauth (eds.), Syntax aus Saarbrücker Sicht. Beiträge der SaRDiS-Tagung zur Dialektsyntax (Zeitschrift Für Dialektologie Und Linguistik Beihefte), vol. 165, 187-219. Stuttgart: Steiner.

Lenz, Alexandra N. 2017. SyHD-atlas: Konjunktiv (würde/täte). SyHD-atlas. http://www.syhd .info/apps/atlas/\#konjunktiv-wuerde-taete (25 September, 2018). 
Lenz, Alexandra N. 2018. The Special Research Programme „German in Austria. Variation Contact - Perception“. Ulrich Ammon \& Marcella Costa (eds.). Sprachwahl im Tourismus - mit Schwerpunkt Europa. Language Choice in Tourism - Focus on Europe. Choix de langues dans le tourisme - focus sur l'Europe. (Sociolinguistica 32), 269-277. Berlin \& Boston: de Gruyter.

Lenz, Alexandra N., Ludwig M. Breuer, Matthias Fingerhuth, Anja Wittibschlager \& Melanie H. Seltmann. 2019 Exploring syntactic variation by means of "Language Production Experiments" Methods from and analyses on German in Austria. To appear in Journal of Linguistic Geography 7, 63-81.' https://doi.org/10.1017/jlg.2019.7

Lenzhofer, Melanie. 2017. Jugendkommunikation und Dialekt: Syntax gesprochener Sprache bei Jugendlichen in Osttirol, (Empirical Linguistics 6). Berlin \& Boston: de Gruyter. https://doi.org/10.1515/9783110503302

Lüdeling, Anke. 2017. Variationistische Korpusstudien. In Marek Konopka \& Angelika Wöllstein (eds.), Grammatische Variation. Empirische Zugänge und theoretische Modellierung (IDS Jahrbuch 2016), 129-144. Berlin: de Gruyter. https://doi.org/10.1515/9783110518214-009

Merkle, Ludwig. 1975. Bairische Grammatik. München: Heimeran.

Moosmüller, Sylvia. 1987. Soziophonologische Variation im gegenwärtigen Wiener Deutsch: eine empirische Untersuchung (Zeitschrift für Dialektologie und Linguistik: Beihefte 56). Stuttgart: Steiner.

Moosmüller, Sylvia. 1991. Hochsprache und Dialekt in Österreich: soziophonologische Untersuchungen zu ihrer Abgrenzung in Wien, Graz, Salzburg und Innsbruck (Sprachwissenschaftliche Reihe; 1). Wien at al.: Böhlau.

Patocka, Franz. 1997. Satzgliedstellung in den bairischen Dialekten Österreichs (Schriften zur deutschen Sprache in Österreich; 20). Frankfurt am Main et al.: Peter Lang.

Rabanus, Stefan. 2008. Morphologisches Minimum: Distinktionen und Synkretismen im Minimalsatz hochdeutscher Dialekte. 1. Auflage. Stuttgart: Franz Steiner Verlag.

Salveit, Laurits. 2008. Anlage der Modussysteme in den deutschen Dialekten. In Wolfgang Putschke, Ulrich Knoop \& Werner Besch (eds.), Dialektologie. 2. Halbband, 1220-1232. Berlin: de Gruyter.

Schallert, Oliver. 2013. Syntaktische Auswertung von Wenkersätzen; eine Fallstudie anhand von Verbstellungsphänomenen in den bairischen (und alemannischen) Dialekten Österreichs. In Rüdiger Harnisch (ed.), Strömungen in der Entwicklung der Dialekte und ihrer Erforschung: Beiträge zur 11. Bayerisch-Österreichischen Dialektologentagung in Passau September 2010 (Regensburger Dialektforum 19), 208-233. Regensburg: Edition Vulpes.

Schmidt, Jürgen Erich \& Joachim Herrgen. 2011. Sprachdynamik. Eine Einführung in die moderne Regionalsprachenforschung. Berlin: Erich Schmidt.

Schwarz, Christian. 2009. Die 'tun'-Periphrase im Deutschen: Gebrauch und Funktion. Saarbrücken: VDM.

Smirnova, Elena. 2006. Die Entwicklung der Konstruktion würde + Infinitiv im Deutschen: eine funktional-semantische Analyse unter besonderer Berücksichtigung sprachhistorischer Aspekte (Studia Linguistica Germania 82). Berlin: de Gruyter. https://doi.org/10.1515/9783110201963

Steinegger, Guido. 1998. Sprachgebrauch und Sprachbeurteilung in Österreich und Südtirol: Ergebnisse einer Umfrage (Schriften zur deutschen Sprache in Österreich; 26). Frankfurt am Main et al.: Peter Lang. 
Stöckle, Philipp. submitted. Dialektvariation an der Schnittstelle von Syntax, Morphologie und Lexik - Der Konjunktiv II in den bairischen Dialekten Österreichs und Südtirols. Submitted to: $Z D L$.

Tatzreiter, Herbert. 2002. Die Wiener Stadtsprache - innovativ und beharrsam. In Zsuzsanna Gerner (ed.), Gesprochene und geschriebene deutsche Stadtsprachen in Südosteuropa und ihr Einfluss auf die regionalen deutschen Dialekte: Internationale Tagung in Pécs, 30.3-2.4.200o, 127-138. Wien: Praesens.

Trudgill, Peter. 1983. On dialect: social and geographical perspectives. Oxford et al.: Blackwell. WBÖ (1970ff.): Wörterbuch der Bairischen Mundarten in Österreich. Kranzmayer, Eberhard (ed. Vol. 1ઐ2) \& Inst. für Österreichische Dialekt- und Namenlexika der Österreichischen Akademie der Wissenschaften (ed. Vol. 3 \& 4 ). Wien: Verlag der Österreichischen Akademie der Wissenschaften.

Wehle, Peter. 1980. Sprechen Sie Wienerisch?: von Adaxl bis Zwutschkerl. Extended and revised version. Wien et al.: Ueberreuter.

Weinreich, Uriel, William Labov \& Marvin I. Herzog. 1968. Empirical foundations for a Theory of Language Change. In Winfred P. Lehmann \& Yakov Malkiel (eds.), Directions for Historical Linguistics, 95-195. Austin: University of Texas Press.

Wiese, Heike. i.p. Neue Dialekte im urbanen Europa. In Beatrix Busse \& Ingo Warnke (eds.), Sprache im urbanen Raum / Language in Urban Space. (Handbuchreihe Sprachwissen 20). Berlin, New York: de Gruyter.

Wiesinger, Peter. 1989. Die Flexionsmorphologie des Verbums im Bairischen. Wien: Verlag der österreichischen Akademie der Wissenschaften.

Wiesinger, Peter. 1992. Zur Interaktion von Dialekt und Standardsprache in Österreich. In Jan A. van Leuvensteijn (ed.), Dialect and standard language: in the English, Dutch, German and Norwegian language areas; seventeen studies in English or German; [proceedings of the Colloquium "Dialect and Standard Language", Amsterdam, 15- 18 October 1990] = Dialekt und Standardsprache, 290-311. Amsterdam et al.: North-Holland PublCo.

Wiesinger, Peter. 1995. Varietäten der gegenwärtigen Wiener Stadtsprache. Gebrauch Einschätzung - Wandel. In Gotthard Lerchner (ed.), Chronologische, areale und situative Varietäten des Deutschen in der Sprachhistoriographie. (Leipziger Arbeiten Zur SprachUnd Kommunikationsgeschichte 2), 447-460. Frankfurt am Main et al.: Lang. Zehetner, Ludwig. 1977. Bairisch (Dialekt, Hochsprache - kontrastiv 2). Düsseldorf: Schwann. Zehetner, Ludwig. 1985. Das bairische Dialektbuch. München: Beck.

Ziegler, Arne, Stefanie Edler, Nina Kleczkowski \& Georg Oberndorfer (eds.). accepted. Urban Matters. Current Approaches of International Sociolinguistic Research. (Studies in Language Variation). Amsterdam et al.: Benjamins.

Zifonun, Gisela, Ludger Hoffmann \& Bruno Strecker. 1997. Grammatik der deutschen Sprache (Schriften des Instituts für deutsche Sprache; 7). Berlin \& New York: de Gruyter. 


\section{Address for correspondence}

Anja Wittibschlager

University of Vienna

Department of German Studies

Universitätsring 1

1010 Vienna

Austria

anja.wittibschlager@univie.ac.at

\section{Co-author information}

Ludwig Maximilian Breuer

ACDH-ÖAW

Austrian Centre for Digital Humanities

Austrian Academy of Sciences

ludwigmaximilian.breuer@oeaw.ac.at

\section{Publication history}

Date received: 21 March 2019

Date accepted: 17 December 2019

Published online: 4 February 2020 